\title{
Utility of 2-Methyl-quinazolin-4(3H)-one in the Synthesis of Heterocyclic Compounds with Anticancer Activity
}

\author{
Aisha Youssif Hassan Helali1, Marwa Taha Mostafa Sarg2*, \\ Makarem Mohamed Said Koraa ${ }^{3}$, Mona Said Fathy El-Zoghbi ${ }^{2}$ \\ ${ }^{1}$ Department of Chemistry, Faculty of Science (Girls), Al-Azhar University, Cairo, Egypt \\ ${ }^{2}$ Department of Organic Chemistry, Faculty of Pharmacy (Girls), Al-Azhar University, Cairo, Egypt \\ ${ }^{3}$ Department of Organic Chemistry, Faculty of Pharmacy, Cairo University, Giza, Egypt \\ Email: m.t.sarg@hotmail.com
}

Received 5 February 2014; revised 5 March 2014; accepted 12 March 2014

Copyright (C) 2014 by authors and Scientific Research Publishing Inc.

This work is licensed under the Creative Commons Attribution International License (CC BY).

http://creativecommons.org/licenses/by/4.0/

(c) (i) Open Access

\begin{abstract}
Quinolino[2,1-b]quinazolines 3 and 4, pyrrolo[2,1-b]quinazoline 5 and various substituted 2-(4chlorostyryl)quinazoline derivatives including: 4-amino derivative 8, 4-hydrazino derivative 9, thiourea derivative 10, thiosemicarbazide derivative 19, 4-benzylidene hydrazinyl derivative 21 , 4-amino thiazolidene derivatives $11,12,13,22$, imidazoquinazolines 15,16 , quinazolinium chloride 14, triazino[4,3-c]quinazolines 17,18 , tetrazino[1,6-c]quinazoline 20 , 4-amino azetidinyl derivative 23 , triazolo[4,3-c]quinazoline 24,4 -amino substituted quinazolines $25,26,27,29$ and quinazolino quinazoline 28 were synthesized through different chemical reactions. The obtained compounds were evaluated for their in vitro antitumor activity against HEPG2 and MCF-7 cell lines compared to the reference drug (doxorubicin). Compounds 18, 19, 20, 23 and 24 were found to be the most active against both cell lines exhibiting $\mathrm{IC}_{50}$ values ranging from $10.82-29.46 \mu \mathrm{M} / \mathrm{L}$ and $7.09-31.85 \mu \mathrm{M} / \mathrm{L}$ against Hep-G2 and MCF-7 cell lines, respectively, in addition to docking study of these five compounds against thymidylate synthase and dihydrofolate reductase enzymes active sites.
\end{abstract}

\section{Keywords}

Quinazoline; Anticancer; DHFR; TS

\footnotetext{
*Corresponding author.
} 


\section{Introduction}

Quinazoline-4(3H)-one ring system has been consistently regarded as promising privileged structural icon owing to its pharmacodynamic versatility in many of its synthetic derivatives as well as in several naturally occurring alkaloids isolated from animals, families of plant kingdoms and micro-organisms [1]-[3].

A systematic perpusal of literature, reveals that quinazoline derivatives encompass a broad spectrum of pharmaceutical activity profile such as antitumor [4]-[10], anti-HIV [11]-[13], antimicrobial [14]-[16], antibacterial, anti-inflammatory [17]-[20], CNS activity [21]-[23] and cardiovascular activity [24] [25]. The quinazoline nucleus is the scaffold of many antitumor drugs mainly acting as inhibitors of tyrosine kinase receptor (TKR) [26]. Over expression of the receptors has been observed in a number of cancers such as breast, ovarian, colon and prostate cancer. Therefore, blocking of tyrosine kinase activity represents a rational approach to cancer therapy [27]-[34]. Also quinazoline derivatives have a therapeutic potential as an anti-invasive agent with potential activity in early and advanced solid tumors, metastatic bone disease and leukemia [35]. So the quinazoline ring is considered as one of the major classes of benzoheterocyclic compounds that have drawn much attention in the field of cancer chemotherapy besides other pharmacological activities [27]-[29]. Moreover, many 4-quinazoline derivatives revealed potent anticancer activity mediated through the inhibition of dihydrofolate reductase enzyme (DHFR) [30] [31] or through inhibition of chki kinase [32].

\section{Results and Discussion}

\subsection{Chemistry}

2-Methyl-quinazolin-4-one was synthesized from the fusion of anthranilic acid with thioacetamide [36] which was utilized as a building unit for novel quinazoline and fused quinazolinone compounds "(Scheme 1)". The extent of the pharmacological effect of a quinazolinone derivative depends on the active group which is attached to it. Recently, several scientists have elucidated that in quinazolinone system sites like position 2 and 3 , can be suitably modified by the introduction of various heterocyclic moieties to show excellent pharmacological results [37] [38].

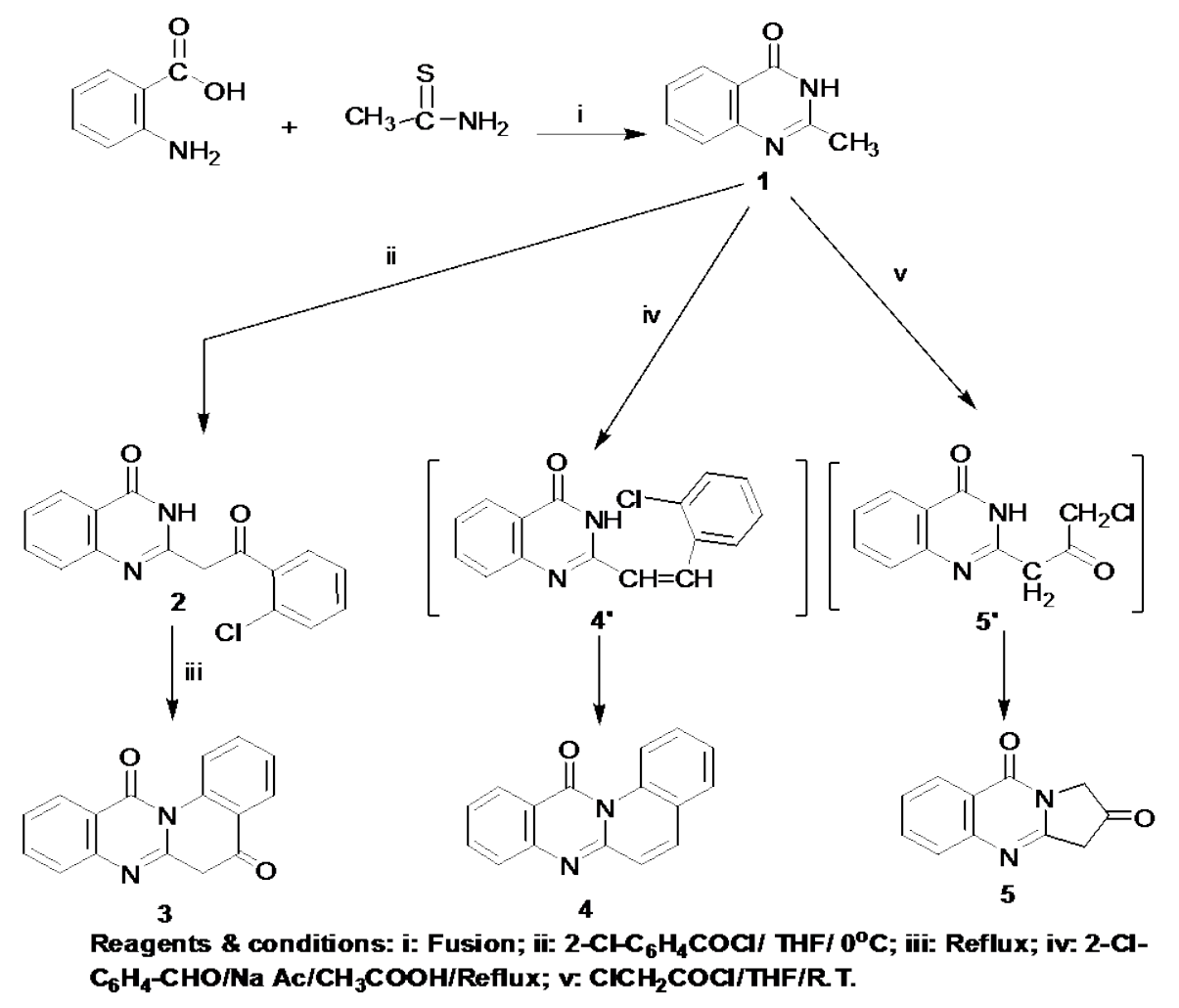

Scheme 1. Synthetic pathways for compounds 1, 2, 3, 4, and 5. 
A known procedure for building up such heterocyclic system is based on cyclization of o-chlorobenzoyl chloride with 2-methyl-quinazolin-4(3H)-one $\mathbf{1}$ in dry THF. The reaction stopped at the stage of formation of 2-[2(2-chlorophenyl)-2-oxoethyl]quinazolin-4(3H)-one 2. This could be explained in the first place by steric hindrance of the o-substituent for optimal position of the reacting groups. We attempted to decrease the effect of the latter by heating compound $\mathbf{2}$ in THF for $2 \mathrm{~h}$. However under this reaction condition, cyclization occurred readily to yield $5 H$-quinolino[2,1-b]quinazolin-5, 12(6H)-dione 3.

The ${ }^{1} \mathrm{H}$-NMR spectrum of compound 2 revealed a singlet at $\delta 4.33 \mathrm{ppm}$ attributed to $\mathrm{CH}_{2}$ protons and a deuterium oxide exchangeable singlet at $\delta 7.73 \mathrm{ppm}$ due to the $\mathrm{NH}$ proton. While, ${ }^{1} \mathrm{H}-\mathrm{NMR}$ spectrum of compound 3 showed a singlet at $\delta 2.49 \mathrm{ppm}$ assigned to $\mathrm{CH}_{2}$ protons and lacked any deuterium oxide exchangeable signals of its precursor.

Attempts to carry out a similar conversion of compound $\mathbf{1}$ into $\mathbf{4}$ by refluxing in THF are unsuccessful. However, the cyclic quinolono [2,1-b]quinazoline $\mathbf{4}$ was obtained through the reaction of compound $\mathbf{1}$ with 2-chlorobenzaldehyde in glacial acetic acid/sodium acetate. In this case, isolation of the intermediate 4 ' was difficult because of its high reactivity which led directly to the cyclic product 4.

Pyrrolo[2,1-b]quinazolindione derivative $\mathbf{5}$ was prepared by the reaction of compound $\mathbf{1}$ with chloroacetyl chloride in dry THF. The reaction is assumed to proceed through chloroacetylation of compound $\mathbf{1}$ at the 2-position followed by intramolecular cyclization on $\mathrm{N}_{3}-\mathrm{NH}$ function with elimination of a hydrochloride molecule to give the target compound $5 .{ }^{1} \mathrm{H}-\mathrm{NMR}$ spectrum of compound $\mathbf{5}$ showed two singlets at $\delta 2.08,2.49 \mathrm{ppm}$ each integrated for two protons attributed to two pyrrolo methylene protons.

Our attention was drawn to the earlier discovery by scientists that modification of methyl group present at the second position of $4(3 \mathrm{H})$-quinazolinone into other chemical intities yielded structural analogues with appreciable biological activity [39] [40] "(Scheme 2)". Therefore, compound 1 was condensed with 4-chlorobenzaldehyde in glacial acetic acid/sodium acetate to afford the chalcone derivative 6 [41]. Chlorination of compound 6 with phosphorous oxychloride was reported to give [42] poor yields of impure chlorinated product. However,<smiles>Cc1nc2ccccc2c(=O)[nH]1</smiles><smiles>CC#CC1CCCCC1</smiles><smiles>Clc1ccc(/C=C/c2nc(Cl)c3ccccc3n2)cc1</smiles><smiles>NNc1nc(/C=C/c2ccc(Cl)cc2)nc2ccccc12</smiles>

Reagents \& conditions: i 4- $\mathrm{Cl}-\mathrm{C}_{6} \mathrm{H}_{4}-\mathrm{CHO} / \mathrm{NaAcl} \mathrm{CH}_{3} \mathrm{COOH} /$ Reflux; ii: $\mathrm{POCl}_{3} / T$.E.A./Reflux; iii: $\mathrm{CH}_{3} \mathrm{COONH}$ /pyridine/Reflux; iv: $\mathrm{NH}_{2} \mathrm{NH}_{2}$ / EtOH/Reflux. 
the addition of triethylamine to the reaction mixture accelerated the reaction speed [43] and afforded 4-chloroquinazoline derivative 7 [41]. Furthermore, amination of compound 7 was carried out by refluxing in pyridine and ammonium acetate to afford the corresponding 4-aminoquinazoline derivative 8. Moreover, hydrazinolysis of compound 7 was accomplished by the use of hydrazine hydrate $99 \%$ in ethanol to afford 4-hydrazinylquinazoline derivative $\mathbf{9}$. The ${ }^{1} \mathrm{H}-\mathrm{NMR}$ spectrum of compound $\mathbf{9}$ showed two deuterium oxide exchangeable singlets at $\delta 4.15$ and $12.26 \mathrm{ppm}$ due to $\mathrm{NH}_{2}$ and $\mathrm{NH}$ protons; respectively.

The work was extended to shed more light on the activity and synthetic potential of the amino group in compound $\mathbf{8}$ "(Scheme 3)". Thus, compound $\mathbf{8}$ was reacted with phenyl isothiocyanate in boiling pyridine to give the corresponding thiourea derivative 10. The ${ }^{1} \mathrm{H}$-NMR spectrum of compound $\mathbf{1 0}$ revealed two deuterium oxide exchangeable singlets at $\delta 7.96$ and $12.13 \mathrm{ppm}$ due to thiourea $\mathrm{N}_{3}$ and $\mathrm{N}_{1}-\mathrm{NH}$ protons; respectively. Furthermore, the thiourea derivative was used as a good starting material for preparation of several polyfunctional thiazolyl derivatives with expected biological activities as the thiazolyl moieties were reported to possess a wide range of pharmacological actions especially anti cancer activity [44]. Therefore, compound $\mathbf{1 0}$ was reacted with ethyl chloroacetate as well as phenacyl chloride in boiling ethanol/sodium acetate to yield 3-phenylthiazolidin-4-one derivative $\mathbf{1 1}$ and 3,4-diphenylthiazolylidene derivative 12; respectively. It was also fused with chloroacetone to give 4-methyl-3-phenyl thiazol-ylidene dreivative 13.

The reaction mechanisms are expected to proceed via elimination of hydrochloride molecules followed by cyclization through ethanol elimination or dehydration. The ${ }^{1} \mathrm{H}-\mathrm{NMR}$ spectrum of compound $\mathbf{1 1}$ revealed a singlet at $\delta 3.46 \mathrm{ppm}$ due to $\mathrm{SCH}_{2}$ protons. The ${ }^{1} \mathrm{H}-\mathrm{NMR}$ spectrum of compounds 12 revealed a singlet at $\delta 7.49$ ppm due to $\mathrm{CH}$-thiazole proton.

However, tricyclic systems in which the quinazoline ring was condensed with imidazole ring have not been adequately studied "(Scheme 4)". Therefore our goal was directed to synthesize imidazoquinazoline derivatives

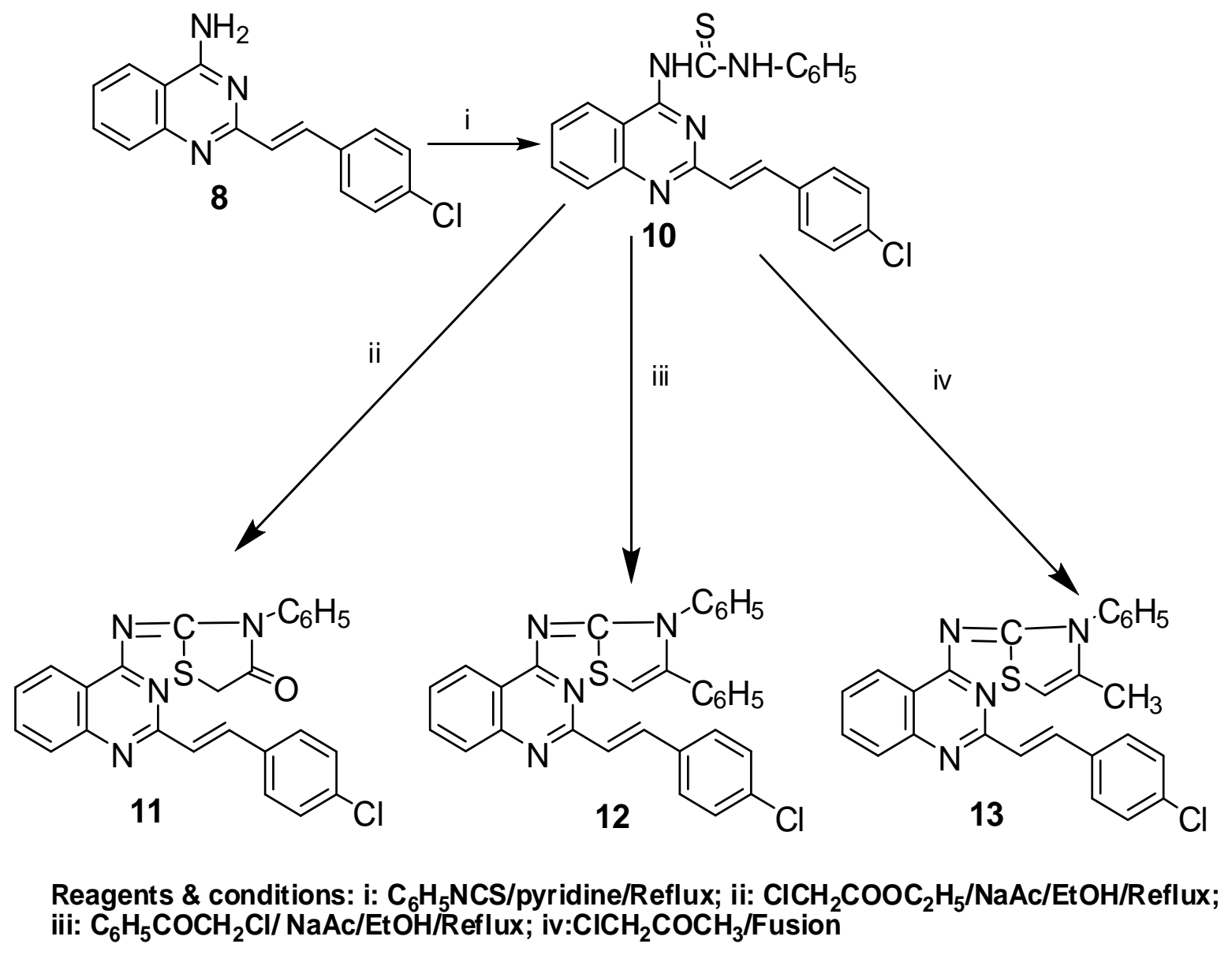


through condensation of compound $\mathbf{8}$ with phenacyl chloride in ethanol, which afforded quinazolin-3-ium chloride derivative $\mathbf{1 4}$ and imidazo[1,2-c]quinazoline derivative $\mathbf{1 5}$ according to the mechanism suggested in the literature [45]. The first step of this process involved the addition of a phenacyl chloride molecule on N-3 position to form the corresponding quinazolinium derivative $\mathbf{1 4}$ which underwent cyclization under the same experimental conditions to give the imidazoquinazoline derivative 15. The ${ }^{1} \mathrm{H}-\mathrm{NMR}$ spectrum of compound $\mathbf{1 4}$ showed a singlet at $\delta 3.63 \mathrm{ppm}$ due to $\mathrm{CH}_{2}$ protons, in addition to two deuterium oxide exchangeable singlets at $\delta 5.18$ and $12.33 \mathrm{ppm}$ due to $\mathrm{NH}_{2}$ protons and $\mathrm{OH}$ tautomer proton; respectively. While the ${ }^{1} \mathrm{H}-\mathrm{NMR}$ spectrum of compound 15 revealed a singlet integrated for one proton at $\delta 7.96 \mathrm{ppm}$ due to $\mathrm{CH}$-imidazole.

Moreover, acylation of the amino group of compound $\mathbf{8}$ with chloroacetyl chloride under anhydrous conditions which underwent intramolecular cyclization on the ring to yield the cyclized product imidazo[1,2-c]quinazolinone derivative 16. In the case of chloroacetyl chloride, the isolation of the intermediate 16' was difficult due to its high reactivity which led directly to the cyclic product 16. The ${ }^{1} \mathrm{H}$-NMR spectrum of compound 16 revealed a singlet at $\delta 3.55 \mathrm{ppm}$ due to $\mathrm{CH}_{2}$ protons of imidazole moiety and another singlet at $\delta 7.50 \mathrm{ppm}$ attributed to the imidazole $=\mathrm{CH}$-tautomer. In addition to a deuterium oxide exchangeable singlet at $\delta 8.51 \mathrm{ppm}$ corresponding to $\mathrm{OH}$ tautomer.

Recently, several biological activities have been reported for [1,2,4]triazino[4,3-c]quinazolines [46], so our aim was extended to the development of different synthetic methods for novel [1,2,4]triazino[4,3-c]quinazolines $\mathbf{1 7}$ and $\mathbf{1 8}$ and investigation of their cytotoxicity and antitumor activity "(Scheme 5)". Therefore, condensation of compound $\mathbf{9}$ with benzoin and with chloroacetyl chloride were applied to furnish the target compounds $\mathbf{1 7}$ and 18; respectively. The ${ }^{1} \mathrm{H}-\mathrm{NMR}$ spectrum of compound $\mathbf{1 7}$ revealed a singlet at $\delta 6.02 \mathrm{ppm}$ due to the triazine $\mathrm{C}_{5}$-proton. While, the ${ }^{1} \mathrm{H}$-NMR spectrum of compound 18 showed a singlet at $\delta 4.25 \mathrm{ppm}$ due to the triazine $\mathrm{CH}_{2}$ protons, in addition to a deuterium oxide exchangeable singlet at $\delta 12.20 \mathrm{ppm}$ attributed to $\mathrm{NH}$ proton. Furthermore, from our survey in the literature, it was found that, a new series of quinazoline compounds was

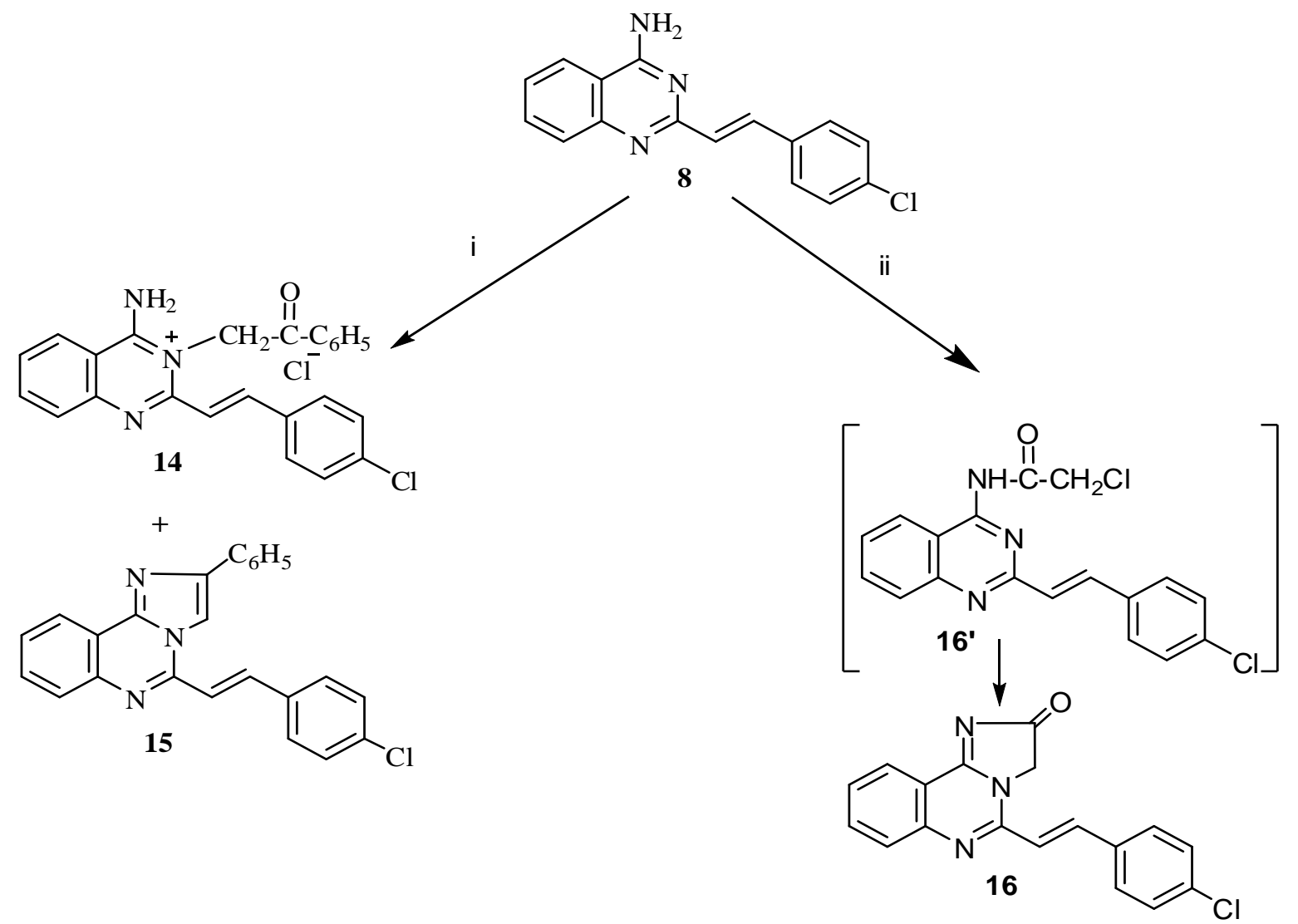

Reagents \& conditions: i: $\mathrm{C}_{6} \mathrm{H}_{5} \mathrm{COCH}_{2} \mathrm{Cl} / \mathrm{EtOH} /$ Reflux; ii: $\mathrm{ClCH}_{2} \mathrm{COCl} / \mathrm{K}_{2} \mathrm{CO}_{3}$ /toluene/Reflux 


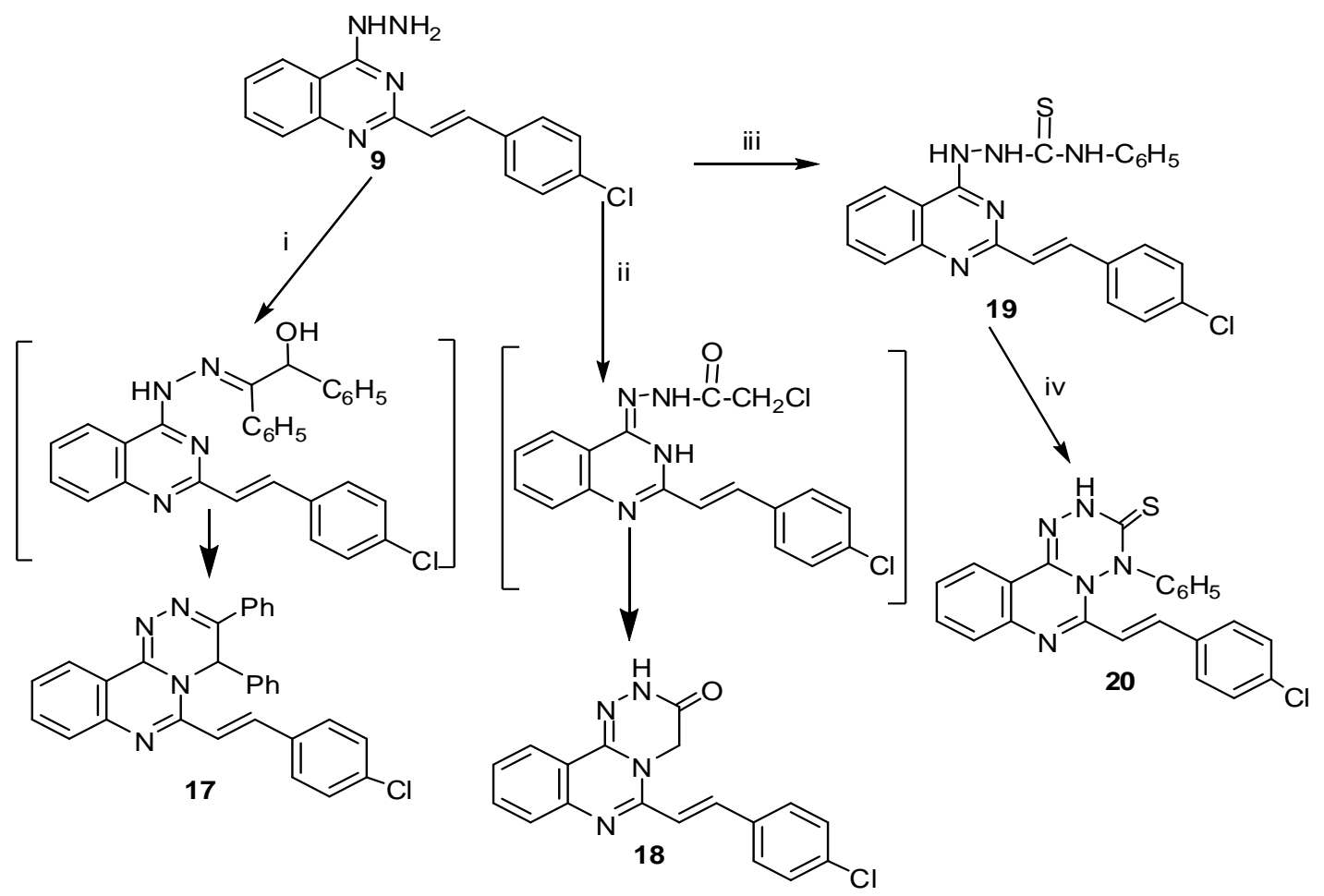

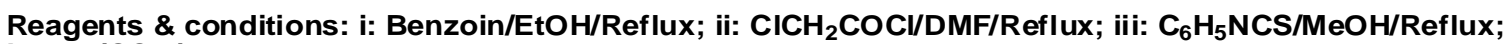
iv: $\mathrm{Br}_{2} / \mathrm{CCl}_{4} / \mathrm{R}$.T.

Scheme 5. Synthetic pathways for compounds 17, 18, 19 and 20.

designed in such a way to accommodate the isothiocyanates, Schiff's bases and amine bridges at positions 2, 3 or 4 of the quinazoline ring. Isothiocyanate, Schiff's base and amide functions are known to contribute in the enhancement of the antitumor activity [4]. The reaction of phenyl isothiocyanate with compound 9 afforded hydrazine carbothioamide derivative 19. The ${ }^{1} \mathrm{H}-\mathrm{NMR}$ spectrum of compound 19 showed a deuterium oxide exchangeable singlet at $\delta 3.98 \mathrm{ppm}$ due to two $\mathrm{NH}$ protons that are attached to $\mathrm{C}=\mathrm{S}$ function and a deuterium oxide exchangeable singlet at $\delta 11.08 \mathrm{ppm}$ due to $\mathrm{NH}$ proton attached to the quinazoline ring which is more deshielded by the nitrogens of the quinazoline ring. The thiosemicarbazide derivative $\mathbf{1 9}$ underwent oxidative cyclization by stirring with bromine to yield $[1,2,4,5]$ tetrazino[1,6-c]quinazoline thione derivative 20. The ${ }^{1} \mathrm{H}$-NMR spectrum of compound 20 showed a deuterium oxide exchangeable singlet at $\delta 4.00 \mathrm{ppm}$ due to $\mathrm{NH}$ proton.

Moreover, the reaction of compound $\mathbf{9}$ with 4-chlorobenzaldehyde in presence of piperidine furnished the Schiff's base $\mathbf{2 1}$ "(Scheme 6)". The Schiff's base $\mathbf{2 1}$ was used as a good starting material for preparation of several quinazoline derivatives. Among which its reaction with thioglycolic acid in presence of anhydrous zinc chloride to furnish the thiazolidinone derivative 22. Furthermore, the reaction of the Schiff's base $\mathbf{2 1}$ with chloroacetyl chloride in presence of triethylamine as a base afforded azetidinone derivative 23 . The ${ }^{1} \mathrm{H}$-NMR spectrum of compound 23 revealed two doublets at $\delta 4.06$ and $4.30 \mathrm{ppm}$ attributed to $\mathrm{CH}-\mathrm{C}_{6} \mathrm{H}_{4}-\mathrm{Cl}$ and $\mathrm{CH}-\mathrm{Cl}$ of the azetidine ring; respectively. In addition to a deuterium oxide exchangeable singlet at $\delta 10.68 \mathrm{ppm}$ attributed to NH proton. Moreover, a group of Slovak's scientists reported that [1,2,4]triazolo[4,3-c]quinazoline derivatives possess considerable in vitro antitumor activity [46]. So we synthesized [1,2,4]triazolo[4,3-c]quinazoline compound $\mathbf{2 4}$ through the cyclization of the Schiff's base $\mathbf{2 1}$ in glacial acetic acid/sodium acetate.

Finally, our work was extended to react 4-chloroquinazoline derivative $\mathbf{7}$ with several primary and secondary amines preparing a series of promising derivatives in order to compare their biological activities "(Scheme 7)". Focusing on setting up a simple, cheap, fast and efficient synthesis; the reaction of compound $\mathbf{7}$ with the primary amine, 2-aminoethanol was accomplished by fusion with excess amine reducing as much as possible both reaction time and temperature so as to preserve the styryl group from reacting. This rapid reaction protocol resulted in the formation of the secondary aminoquinazoline derivative 25 in good yields. The ${ }^{1} \mathrm{H}-\mathrm{NMR}$ spectrum of 


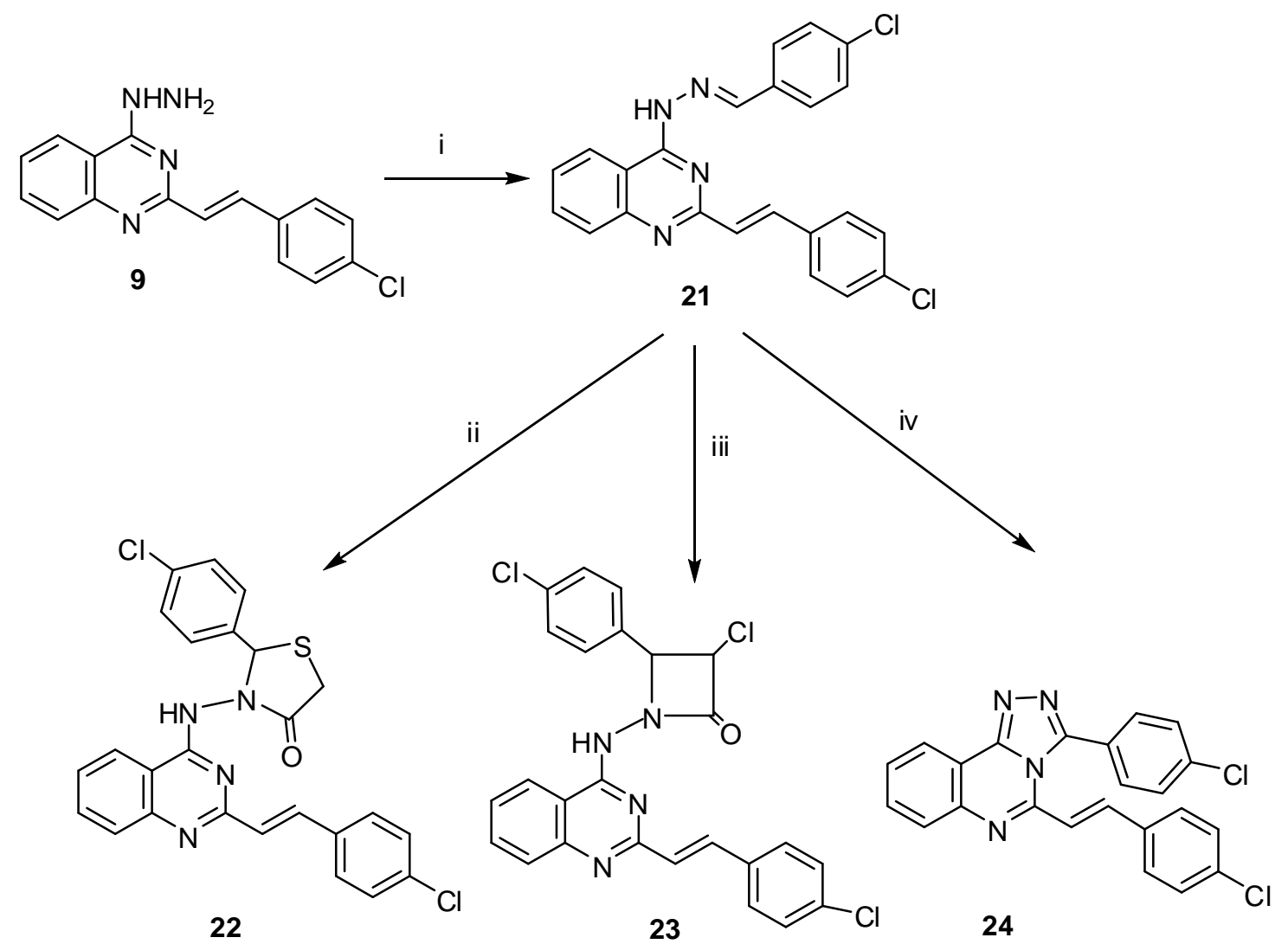

Reagents \& conditions: i: 4- $\mathrm{Cl}-\mathrm{C}_{6} \mathrm{H}_{4} \mathrm{CHO} / \mathrm{EtOH} /$ piperidine/Reflux;

ii: $\mathrm{HSCH}_{2} \mathrm{COOH} / \mathrm{ZnCl} /$ /benzenel/Reflux;

iii: $\mathrm{ClCH}_{2} \mathrm{COCI/T.E.A./DMF/Reflux;} \mathrm{iv:} \mathrm{CH}_{3} \mathrm{COOH/NaAc/Reflux}$.

Scheme 6. Synthetic pathways for compounds 21, 22, 23 and 24.

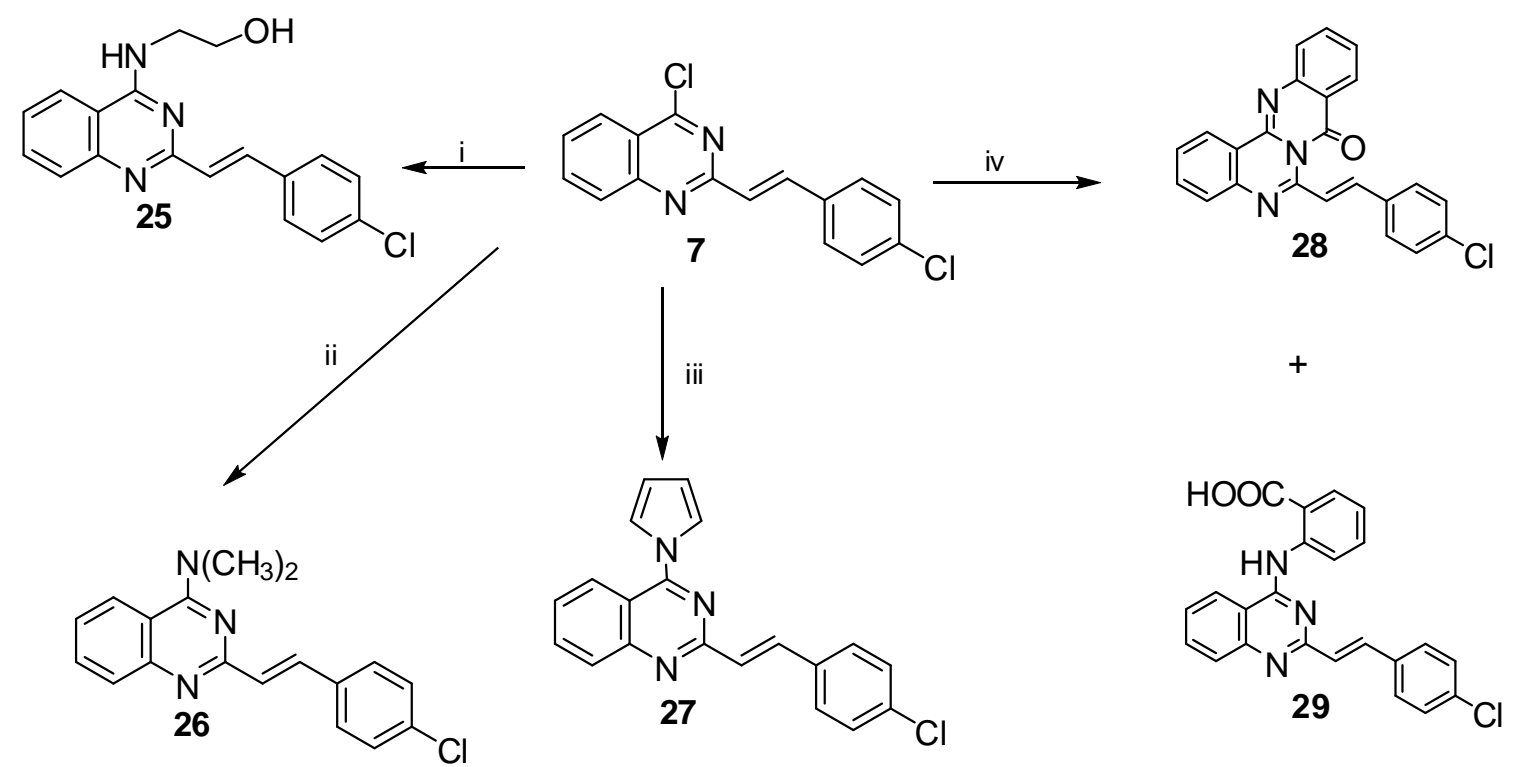

Reagents \& conditions: i: $\mathrm{H}_{2} \mathrm{NCH}_{2} \mathrm{CH}_{2} \mathrm{OH} /$ Fusion; ii: $\left(\mathrm{CH}_{3}\right)_{2} \mathrm{NH} /$ Fusion; iii: pyrrole/Fusion; iv: Anthranilic acid/ $\mathrm{CH}_{3} \mathrm{COOH} /$ Fusion

Scheme 7. Synthetic pathways for compounds 25, 26, 27, 28 and 29. 
compound 25 showed a multiplet at $\delta 3.66-3.71 \mathrm{ppm}$ integrated for four protons corresponding to two $\underline{\mathrm{CH}}_{2}$ protons and two deuterium oxide exchangeable singlets at $\delta 4.40$ and $\delta 12.25 \mathrm{ppm}$ attributed to $\mathrm{OH}$ and $\mathrm{NH}$ protons, respectively. Moreover, the substrate $\mathbf{7}$ was also reacted very easily with secondary amines such as dimethylamine and pyrrole by the same manner as aminoethanol to yield tertiary amino quinazolines $\mathbf{2 6}$ and $\mathbf{2 7}$; respectively in very good yields.

Furthermore, compound $\mathbf{7}$ was reacted with anthranilic acid in glacial acetic acid to afford the polycyclic quinazoline derivative $\mathbf{2 8}$ while hot, while the reaction filtrate yielded the open chain secondary aminoquinazoline derivative 29 that bears a free carboxylic group which could possibly alter the biological properties including cytotoxic activity [47]. However, the reaction is expected to proceed through formation of the secondary aminobenzoic acid derivative $\mathbf{2 9}$ first which carried out intramolecular dehydration reaction leading to the cyclic quinazolinoquinazoline derivative 28. The ${ }^{1} \mathrm{H}-\mathrm{NMR}$ spectrum of compound 29 showed two deuterium oxide exchangeable singlets at $\delta 8.76$ and $\delta 12.18 \mathrm{ppm}$ attributed to $\mathrm{NH}$ and carboxylic $\mathrm{OH}$ protons; respectively. While the ${ }^{1} \mathrm{H}$-NMR spectrum of compound 28 lacked any deuterium oxide exchangeable singlets due to $\mathrm{NH}$ and $\mathrm{OH}$ protons.

\subsection{Biology}

The six dose growth inhibition percent and the $\mathrm{IC}_{50}$ values of the tested compounds (2 - 29) against liver HepG2 and breast MCF-7 cell lines are represented in Tables 1 and 2; respectively.

\begin{tabular}{|c|c|c|c|c|c|c|c|}
\hline \multirow{2}{*}{$\begin{array}{c}\text { Sample conc. }(\mu \mathrm{g} / \mathrm{mL}) \\
\text { Compound No. }\end{array}$} & \multicolumn{6}{|c|}{ Growth inhibition \% } & \multirow{2}{*}{$\mathbf{I C}_{50}(\mu \mathrm{M} / \mathrm{L})$} \\
\hline & 50 & 25 & 12.5 & 6.25 & 3.13 & 1.6 & \\
\hline 2 & 81.73 & 65.02 & 39.08 & 21.46 & 10.59 & 3.20 & 59.73 \\
\hline 3 & 64.81 & 56.58 & 43.37 & 34.70 & 23.03 & 11.54 & 71.76 \\
\hline 4 & 73.61 & 57.42 & 40.81 & 33.50 & 24.62 & 15.84 & 78.86 \\
\hline 5 & 57.48 & 48.74 & 35.82 & 27.14 & 20.38 & 15.55 & $>100$ \\
\hline 6 & 87.08 & 66.57 & 41.14 & 25.41 & 9.19 & 1.38 & 59.93 \\
\hline 7 & 85.04 & 72.69 & 50.38 & 28.67 & 9.75 & 1.27 & 41.33 \\
\hline 8 & 83.71 & 61.58 & 33.25 & 12.68 & 4.22 & 0.00 & 70.82 \\
\hline 9 & 83.46 & 52.65 & 33.96 & 17.07 & 8.26 & 2.11 & 78.38 \\
\hline 10 & 90.38 & 87.53 & 77.16 & 47.12 & 31.39 & 12.58 & 16.35 \\
\hline 11 & 75.41 & 53.45 & 42.52 & 30.35 & 16.69 & 8.86 & 46.27 \\
\hline 12 & 71.28 & 58.09 & 26.91 & 18.02 & 11.68 & 4.86 & 42.25 \\
\hline 13 & 72.66 & 39.07 & 18.28 & 9.13 & 1.84 & 0.00 & 72.91 \\
\hline 14 & 74.81 & 37.46 & 17.07 & 6.94 & 3.12 & 0.00 & 76.78 \\
\hline 15 & 88.97 & 77.44 & 61.57 & 45.44 & 26.13 & 14.39 & 20.99 \\
\hline 16 & 84.36 & 50.68 & 21.46 & 8.30 & 2.17 & 0.00 & 76.01 \\
\hline 17 & 83.76 & 73.57 & 39.05 & 30.43 & 20.19 & 13.94 & 34.96 \\
\hline 18 & 83.65 & 70.57 & 59.45 & 27.08 & 10.52 & 4.84 & 31.85 \\
\hline 19 & 92.11 & 86.69 & 77.52 & 38.72 & 20.64 & 10.36 & 18.79 \\
\hline 20 & 84.07 & 73.89 & 53.36 & 29.14 & 16.87 & 7.53 & 27.04 \\
\hline 21 & 85.88 & 74.64 & 48.76 & 31.68 & 16.04 & 7.46 & 31.34 \\
\hline 22 & 80.15 & 66.32 & 28.25 & 16.48 & 5.81 & 2.42 & 39.84 \\
\hline 23 & 91.03 & 83.09 & 74.41 & 60.58 & 48.53 & 25.08 & 7.09 \\
\hline 24 & 92.14 & 86.26 & 78.62 & 63.85 & 40.19 & 23.47 & 10.58 \\
\hline 25 & 73.37 & 46.82 & 30.46 & 16.22 & 5.85 & 1.27 & 86.15 \\
\hline 26 & 67.52 & 55.94 & 26.38 & 20.59 & 13.84 & 6.39 & 72.81 \\
\hline 27 & 72.18 & 38.42 & 14.26 & 3.52 & 1.04 & 0.00 & $>100$ \\
\hline 28 & 70.26 & 31.38 & 20.41 & 12.84 & 4.78 & 1.06 & 96.61 \\
\hline 29 & 91.26 & 80.92 & 66.71 & 43.36 & 21.89 & 10.33 & 19.95 \\
\hline Doxorubicin & 89.05 & 85.71 & 83.10 & 78.97 & 69.68 & 51.75 & 8.55 \\
\hline
\end{tabular}


Table 2. Six dose growth inhibition percent and $\mathrm{IC}_{50}$ values of the test compounds against MCF-7 cell line.

\begin{tabular}{|c|c|c|c|c|c|c|c|}
\hline \multirow{2}{*}{$\begin{array}{l}\text { Sample conc. } \\
(\mu \mathrm{g} / \mathrm{mL}) \\
\text { Compound No. }\end{array}$} & \multicolumn{6}{|c|}{ Growth inhibition \% } & \multirow{2}{*}{$\begin{array}{c}\text { IC }_{50} \\
(\mu \mathrm{M} / \mathrm{L})\end{array}$} \\
\hline & 50 & 25 & 12.5 & 6.25 & 3.13 & 1.6 & \\
\hline 2 & 69.06 & 52.75 & 30.68 & 16.86 & 7.14 & 1.53 & 78.52 \\
\hline 3 & 58.28 & 47.59 & 30.12 & 21.88 & 10.66 & 4.22 & $>100$ \\
\hline 4 & 62.47 & 46.84 & 37.45 & 25.22 & 14.08 & 8.56 & $>100$ \\
\hline 5 & 53.68 & 40.22 & 28.46 & 13.64 & 5.78 & 1.87 & $>100$ \\
\hline 6 & 72.05 & 45.17 & 21.46 & 8.28 & 2.62 & 100.00 & $>100$ \\
\hline 7 & 71.61 & 50.54 & 36.18 & 27.03 & 20.66 & 9.49 & 81.66 \\
\hline 8 & 71.41 & 50.76 & 36.27 & 14.04 & 5.18 & 1.85 & 86.48 \\
\hline 9 & 74.68 & 48.14 & 29.06 & 10.44 & 3.82 & 0.00 & 90.54 \\
\hline 10 & 76.22 & 45.61 & 30.19 & 12.66 & 4.78 & 1.83 & 68.75 \\
\hline 11 & 70.92 & 47.86 & 31.05 & 21.84 & 10.47 & 5.62 & 59.87 \\
\hline 12 & 75.42 & 50.25 & 27.47 & 18.64 & 9.43 & 3.76 & 48.26 \\
\hline 13 & 65.02 & 37.83 & 20.46 & 8.22 & 2.68 & 0.00 & 79.96 \\
\hline 14 & 68.66 & 33.21 & 9.35 & 2.86 & 0.00 & 0.00 & 84.59 \\
\hline 15 & 79.02 & 65.77 & 41.36 & 20.85 & 10.28 & 3.54 & 44.37 \\
\hline 16 & 84.06 & 63.33 & 37.77 & 20.52 & 12.47 & 5.81 & 57.63 \\
\hline 17 & 62.71 & 53.62 & 37.46 & 18.81 & 6.17 & 2.35 & 47.03 \\
\hline 18 & 86.18 & 71.67 & 58.64 & 37.86 & 28.08 & 12.14 & 29.46 \\
\hline 19 & 84.06 & 73.17 & 60.24 & 52.42 & 36.83 & 11.66 & 13.46 \\
\hline 20 & 89.46 & 74.83 & 61.25 & 41.18 & 30.19 & 11.27 & 20.98 \\
\hline 21 & 72.82 & 60.69 & 63.29 & 24.16 & 17.25 & 10.88 & 46.41 \\
\hline 22 & 82.66 & 70.58 & 51.37 & 21.07 & 9.14 & 1.87 & 24.80 \\
\hline 23 & 89.14 & 72.82 & 61.28 & 52.69 & 30.26 & 10.50 & 11.94 \\
\hline 24 & 93.03 & 81.77 & 72.32 & 59.05 & 43.28 & 28.46 & 10.82 \\
\hline 25 & 68.46 & 42.54 & 28.79 & 14.28 & 5.32 & 1.87 & 99.08 \\
\hline 26 & 59.46 & 47.67 & 38.31 & 25.22 & 13.96 & 7.64 & 96.76 \\
\hline 27 & 61.06 & 36.97 & 15.82 & 3.15 & 0.00 & 0.00 & $>100$ \\
\hline 28 & 65.06 & 51.89 & 32.54 & 18.76 & 9.47 & 2.62 & 62.14 \\
\hline 29 & 78.22 & 61.86 & 45.08 & 19.22 & 10.47 & 3.84 & 40.40 \\
\hline Doxorubicin & 90.76 & 88.45 & 84.26 & 77.78 & 70.82 & 55.16 & 8.90 \\
\hline
\end{tabular}

The thiourea derivative $\mathbf{1 0}$ exhibited strong anticancer activity against liver cancer cell line about half the activity of doxorubicin $\left(\mathrm{IC}_{50}=8.55 \mu \mathrm{M} / \mathrm{L}\right.$ ) with $\mathrm{IC}_{50} 16.35 \mu \mathrm{M} / \mathrm{L}$. However, it showed moderate activity against breast cancer MCF-7 with IC $_{50} 68.75 \mu \mathrm{M} / \mathrm{L}$. Fusion of [1,2,4]triazine or [1,2,4,5]tetrazine to the quinazoline back bone as in compounds $\mathbf{1 8}$ and $\mathbf{2 0}$ resulted in marked increase in activity against both HepG2 and MCF-7 cell lines exerting $\mathrm{IC}_{50} 31.85$ and $27.04 \mu \mathrm{M} / \mathrm{L}$ against HepG2 cell line and 29.46 and $20.98 \mu \mathrm{M} / \mathrm{L}$ against MCF-7 cell line; respectively. It is to be noted that, the presence of a phenyl thiosemicarbazide side chain attached to the $\mathrm{C}_{4}$-quinazoline ring as in compound $\mathbf{1 9}$ exhibited marked anticancer activity against both HepG2 and MCF-7 cell lines exerting $\mathrm{IC}_{50} 18.79$ and $13.46 \mu \mathrm{M} / \mathrm{L}$; respectively. However, incorporating N-azetidinone4-amino moiety to the quinazoline back bone as in compound 23 resulted in improvement in activity against both HepG2 and MCF-7 cell lines which exhibited slightly better anticancer activity against HepG2 (IC 50 7.09 $\mu \mathrm{M} / \mathrm{L}$ ) than the reference drug doxorubicin ( $\mathrm{IC}_{50} 8.55 \mu \mathrm{M} / \mathrm{L}$ ). While, it showed comparable activity to that of doxorubicin ( $\mathrm{IC}_{50} 8.90 \mu \mathrm{M} / \mathrm{L}$ ) against MCF-7 exerting $\mathrm{IC}_{50} 11.94 \mu \mathrm{M} / \mathrm{L}$.

Furthermore, fusion of triazole ring to quinazoline nucleus as in compound $\mathbf{2 4}$ resulted in marked increase in activity against both HepG2 and MCF-7 cell lines exerting IC 5010.58 and $10.82 \mu \mathrm{M} / \mathrm{L}$; respectively which represent a strong anticancer agent against these two cell lines (Figures 1 and 2). Moreover, the presence of 


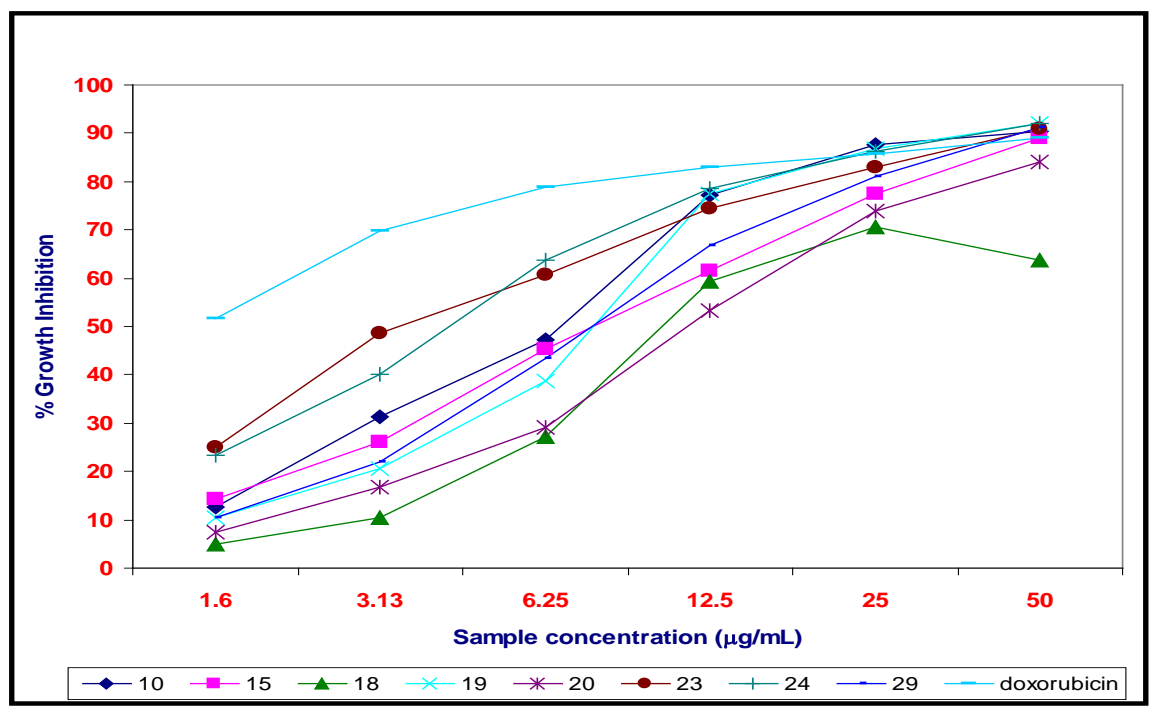

Figure 1. Growth inhibition curves of most active compounds against HepG2 cell line.

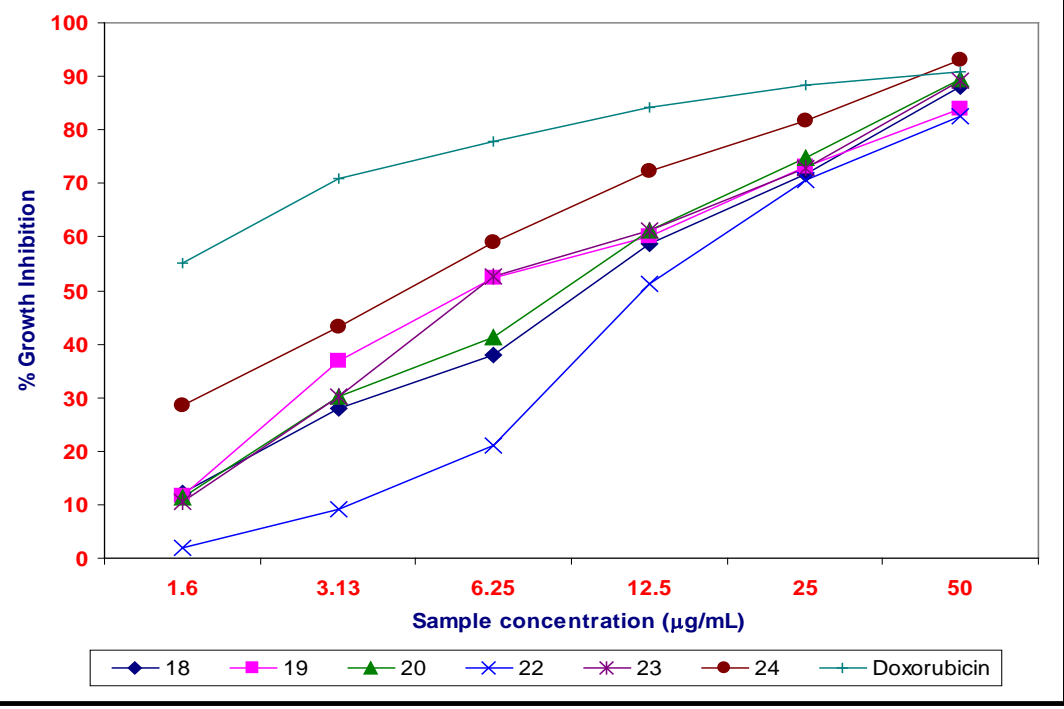

Figure 2. Growth inhibition curves of most active compounds against MCF-7 cell line.

2-amino benzoic acid moiety on the $\mathrm{C}_{4}$-quinazoline ring as in compound $\mathbf{2 9}$ exhibited remarkable increase in activity towards HepG2 cell line showing $\mathrm{IC}_{50} 19.95 \mu \mathrm{M} / \mathrm{L}$.

\subsection{Computer Aided Docking}

Five representative active anticancer compounds 18, 19, 20, 23 and 24 were subjected to docking using Molecular Operating Environment (MOE) program [48] on the 3D structure of two enzymes, namely; thymidylate synthase (TS) and dihydrofolate reductase (DHFR). The study also shows the enzyme interactions with their substrates; 2'-deoxyuridine-5'-monophosphate (DUMP) and methotrexate (MTX); respectively.

\subsubsection{Docking on the Active Site of Thymidylate Synthase}

MOE docking studies of the inhibitors were performed using thymidylate synthase co-crystallized with the sub- 
strate DUMP(PDB ID: IBID) as a template.

1) Docking of DUMP into TS active site revealed that:

Several interactions were considered to be responsible for the observed affinity of the compound. As it acts as a hydrogen bond acceptor with the backbone Asp 169 residue and the side chain residues; Arg 166, Ser 167, Asn 177, His 207 and Tyr 209 as well as hydrogen bond donor with the side chain residues; Asn 177, His 207 and Tyr 209. In addition to hydrophobic interactions with: Arg 21, Cys 146, His 147, Gln 165, Arg 166, Ser 167, Cys 168, Asp 169, Gly 173, Asn 177, His 207 and Tyr 209 as shown in Figure 3(a).
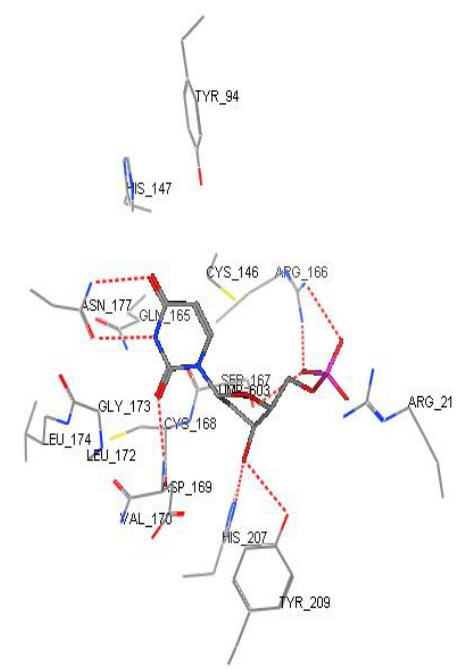

(His)

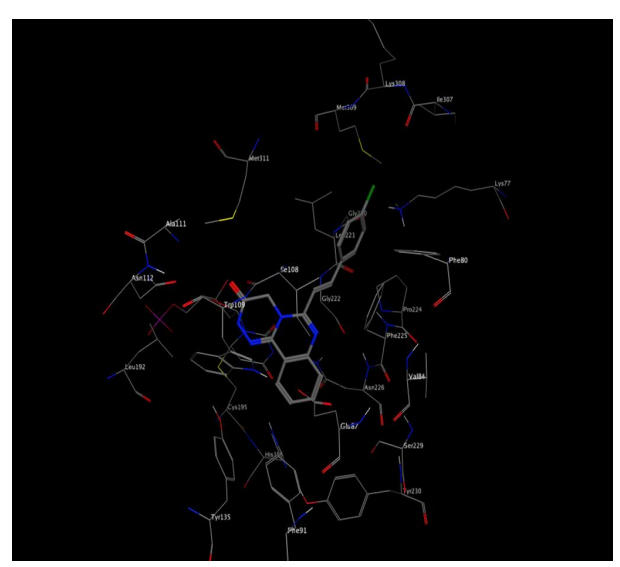

(a)

G1y

GIn
165
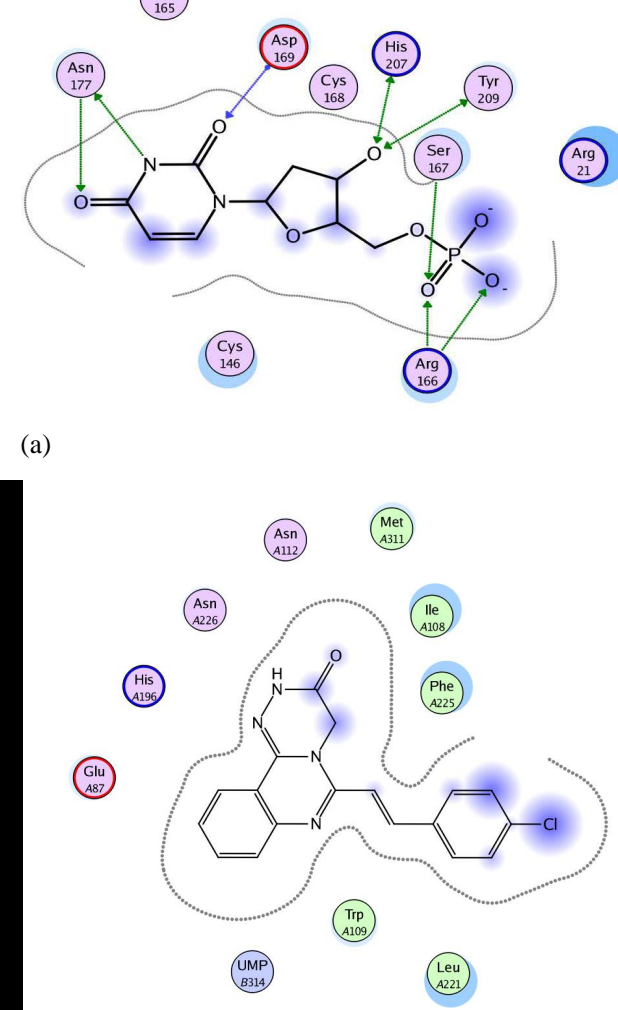

(b)
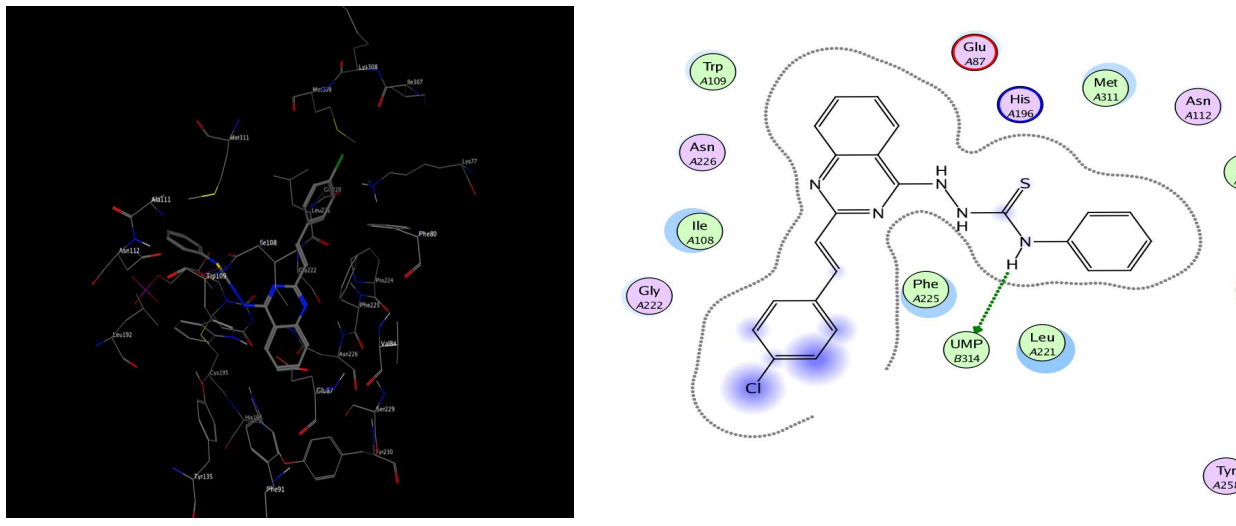

Aitid

(Lev)

(Ar9)

T25:

(c) 

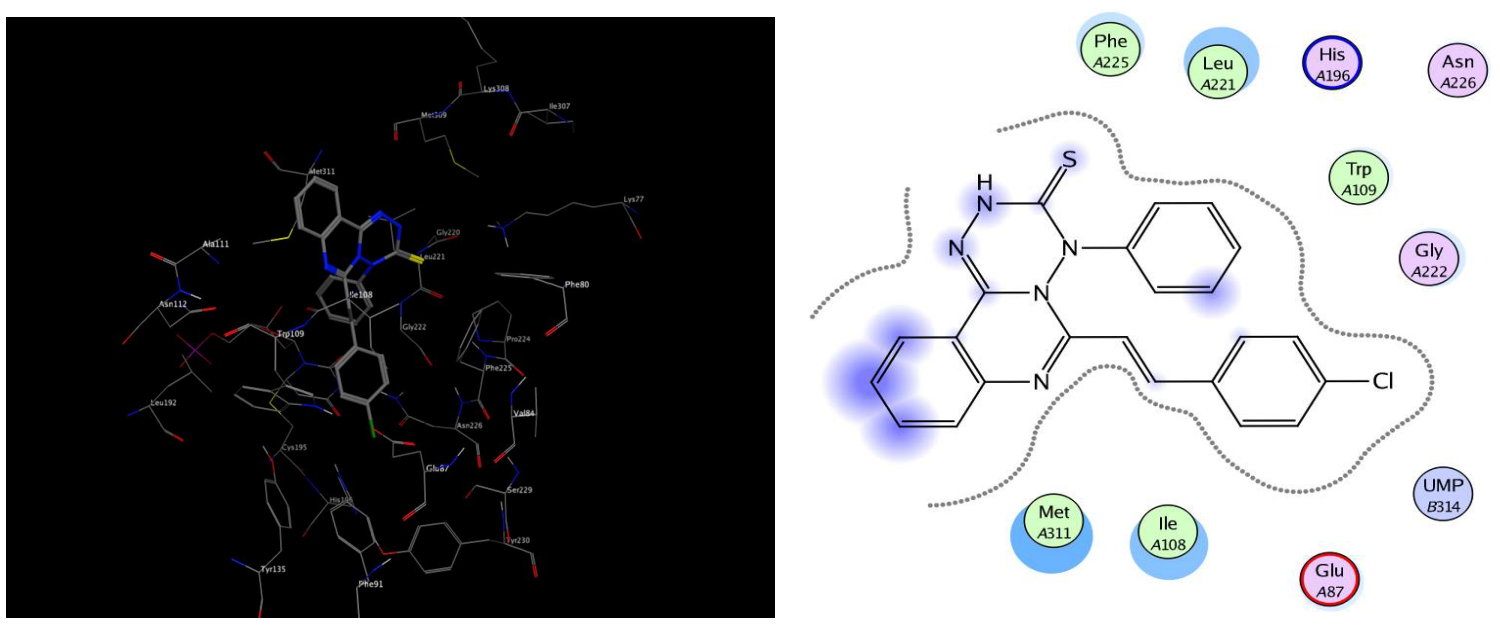

(d)
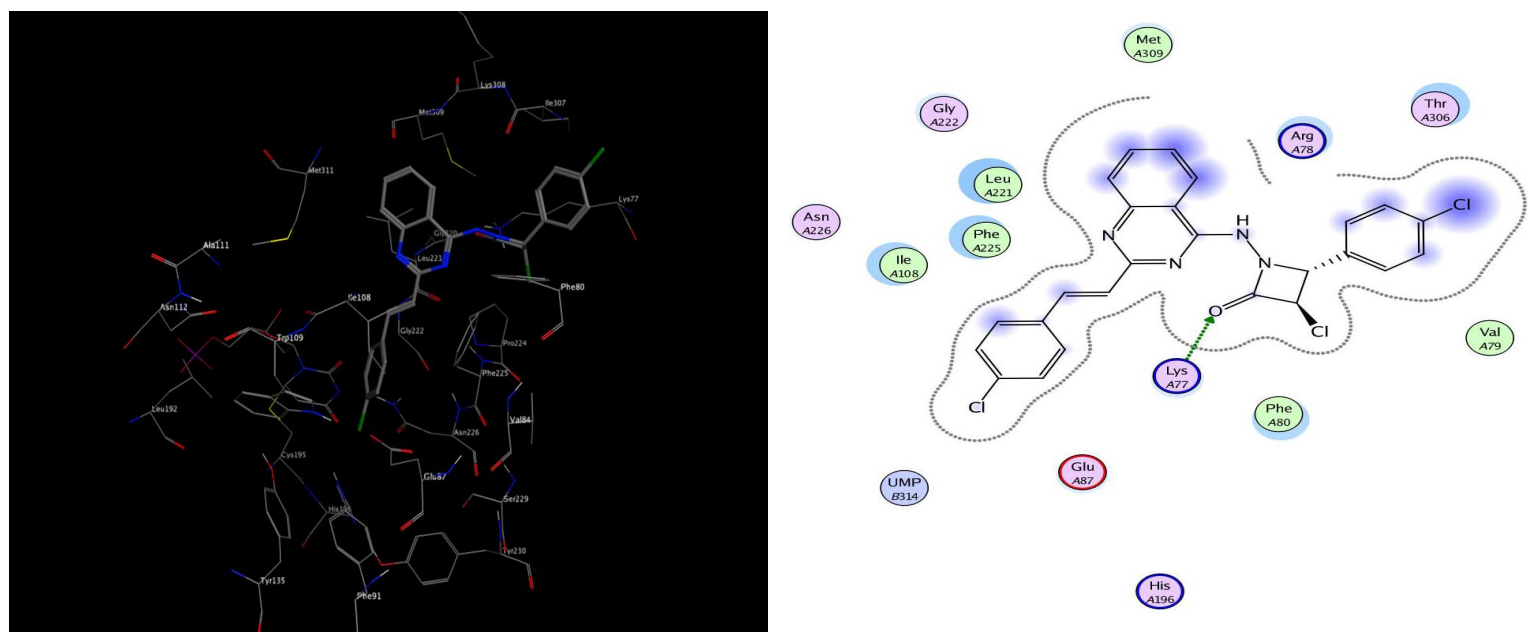

(e)
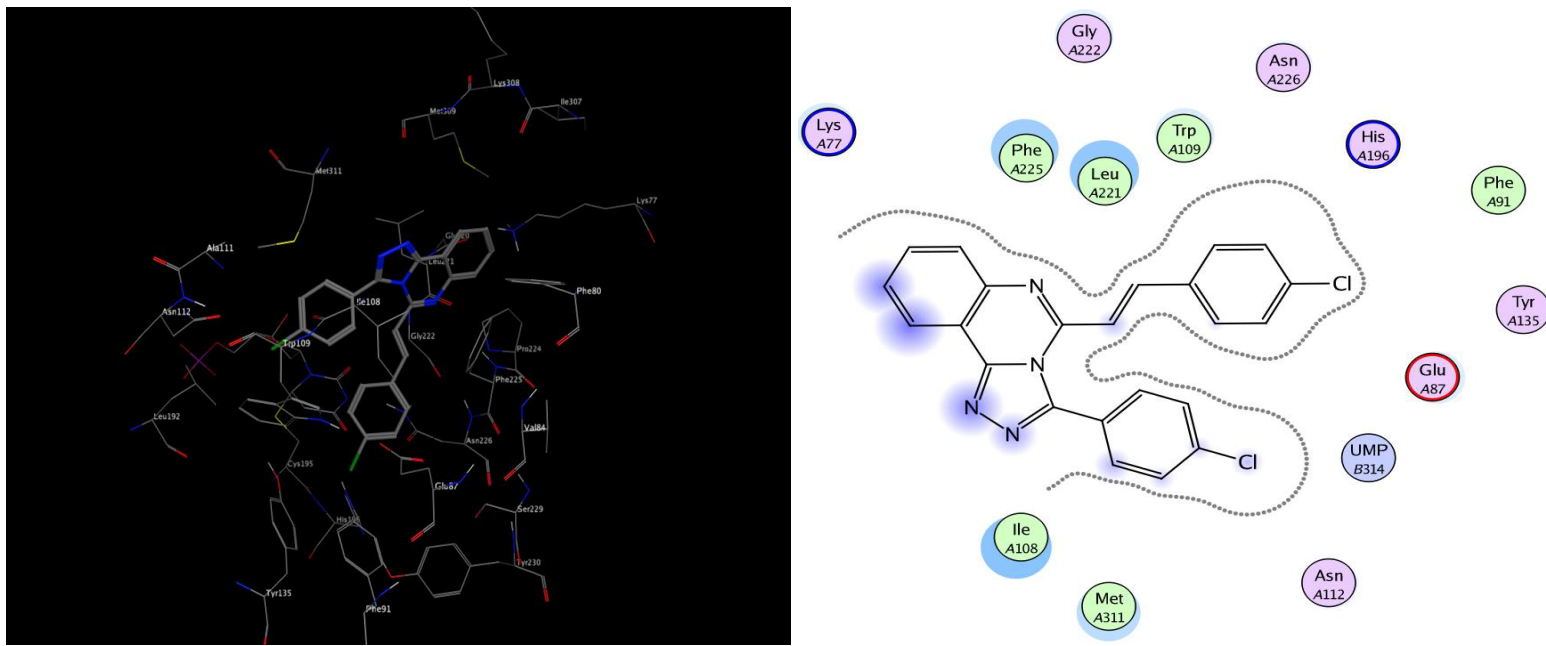

(f)

Figure 3. (a) Docking of DUMP in the active site of TS; (b) Docking of compound $\mathbf{1 8}$ in the active site of TS; (c) Docking of compound 19 in the active site of TS; (d) Docking of compound 20 in the active site of TS; (e) Docking of compound 23 in the active site of TS; (f) Docking of compound $\mathbf{2 4}$ in the active site of TS. 
2) Docking of compound 18 into TS active site revealed:

The presence of hydrophobic interactions between the chlorine atom and the styryl moiety as well as the triazine ring $\mathrm{C}_{5}$ carbon and $\mathrm{C}_{6}$ carbonyl function with the following amino acid residues: Glu 87, Ile 108, Trp 109, Asn 112, His 196, Leu 221, Phe 225, Asn 226, Met 311 and Ump 314 as shown in Figure 3(b).

3) Docking of compound 19 into TS active site revealed:

The interaction of the NH group that is attached to the phenyl ring as a hydrogen bond donor with the side chain residue Ump $314(2.89 \AA)$ at a strength of $4.7 \%$. This beside many hydrophobic interactions concerning the chlorine atom, styryl moiety and $\mathrm{C}=\mathrm{S}$ function with the following amino acid residues: Arg 50, Glu 87, Ile 108, Trp 109, Asn 112, Leu 192, His 196, Leu 221, Gly 222, Phe 225, Asn 226, Tyr 258, Met 311, Ala 312 and Ump 314 as shown in Figure 3(c).

4) Docking of compound 20 into TS active site:

Displayed many hydrophobic interactions between quinazoline- $\mathrm{C}_{5,6,7}$ carbons, tetrazine $\mathrm{NH}$, tetrazine $\mathrm{N}_{2}$ and $\mathrm{C}=\mathrm{S}$ function, in addition to phenyl ring with many amino acid residues which are; Glu 87, Ile 108, Trp 109, His 196, Leu 221, Gly 222, Phe 225, Asn 226, Met 311 and Ump 314 as shown in Figure 3(d).

5) Docking of compound 23 into TS active site illustrated:

The interaction of carbonyl oxygen atom as a hydrogen bond acceptor with the side chain residue Lys77 (2.90 $\AA$ ) at a strength of $46.9 \%$ as well as hydrophobic interactions involving azetidine- $\mathrm{C}_{4}$-4-chlorophenyl moiety, styryl moiety, quinazoline- $\mathrm{C}_{4}-\mathrm{NH}$ function and quinazoline- $\mathrm{C}_{5,6,7,8}$ carbons with the following amino acid residues: Lys 77, Arg 78, Val 79, Phe 80, Glu 87, Ile 108, His 196, Leu 221, Gly 222, Phe 225, Asn 226, Thr 306, Met 309 and Ump 314 as shown in Figure 3(e).

6) Docking of compound $\mathbf{2 4}$ into TS active site showed:

Hydrophobic interactions between triazole- $\mathrm{N}_{1}$ and $\mathrm{N}_{2}$, quinazoline- $\mathrm{C}_{5}$ and $\mathrm{C}_{6}$, triazole- $\mathrm{C}_{3}-4-$ chlorophenyl moiety and styryl moiety with the following amino acid residues: Lys 77, Glu 87, Phe 91, Ile 108, Trp 109, Asn 112, Tyr 135, His 196, Leu 221, Gly 222, Phe 225, Asn 226, Met 311 and Ump 314 as shown in Figure 3(f).

\subsubsection{Docking on the Active Site of Dihydrofolate Reductase (DHFR)}

MOE docking studies of the inhibitors were performed using dihydrofolate reductase co-crystallized with me thotrexate (PDB ID: 4DFR) as a template.

1) Docking of MTX into DHFR active site revealed that:

Hydrogen bond interactions beside hydrophobic interactions were considered to be responsible for the observed affinity as it acts as a hydrogen bond donor to the backbone Ile 5 and Ile 94 residues and the side chain Asp 27 residue. It also acts as a hydrogen bond accepter to Arg 52 and Arg 57 residues. This beside many hydrophobic interactions with various amino acid residues: ILe 5, Ala 6, Ala 7, Asp 27, Leu 28, Phe 31, Lys 32, Ser 49, Ile 50, Arg 52, Leu 54, Arg 57, Ile 94, Tyr 100 and Thr 113 as shown in Figure 4(a).

2) Docking of compound 18 into DHFR active site:

Revealed the interaction of quinazoline- $\mathrm{N}_{1}$ atom as a hydrogen bond acceptor with the side chain residue Ser $59(2.93 \AA)$ at a strength of $43.7 \%$, in addition to the interaction of carbonyl group oxygen as a hydrogen bond acceptor with the side chain residue Tyr 121 (2.86 $\AA$ ) at a strength of $18.9 \%$ beside many hydrophobic interactions among quinazoline- $\mathrm{C}_{6}$ atom, chlorine atom, styryl moiety and triazine- $\mathrm{C}_{5}$ with the following amino acid residues: Val 8, Ile 16, Lys 55, Thr 56, Ser 59, Ile 60, Pro 61, Val 115, Gly 117 and Tyr 121 as shown in Figure 4(b).

3) Docking of compound 19 into DHFR active site:

Illustrated the interactions of the two $\mathrm{NH}$ functions on both sides of $\mathrm{C}=\mathrm{S}$ function as hydrogen bond donors with the same side chain residue Ser $59(2.49 \AA, 1.71 \AA)$ at a strength of $7.7 \%$ and $90 \%$ as well as hydrophobic interactions with the chlorine atom, styryl moiety, phenyl group, quinazoline ring and quinazoline- $\mathrm{C}_{4}-\mathrm{NH}$ moiety with the following amino acid residues: Ala 9, Ile 16, Asp 21, Leu 22, Phe 31, Phe 34, Lys 55, Thr 56, Ser 59, Asn 64, Leu 67, Arg 70 and Thr 146 as shown in Figure 4(c).

4) Docking of compound 20 into DHFR active site showed:

The interaction of the tetrazine-NH function as a hydrogen bond donor with the side chain residue Asp 21 (1.32 $\AA$ ) at a strength of 50.8\%. In addition to hydrophobic interactions concerning the sulphur atom, phenyl group, quinazoline- $\mathrm{C}_{7,8}$ and styryl moiety with the following amino acid residues: Ile 7, Val 8, Ala 9, Ile 16, Gly 20, Asp 21, Leu 22, Glu 30, Phe 31, Phe 34, Thr 56, Ser 59, Ile 60 and Thr 146 as shown in Figure 4(d).

5) Docking of compound 23 into DHFR active site displayed: 

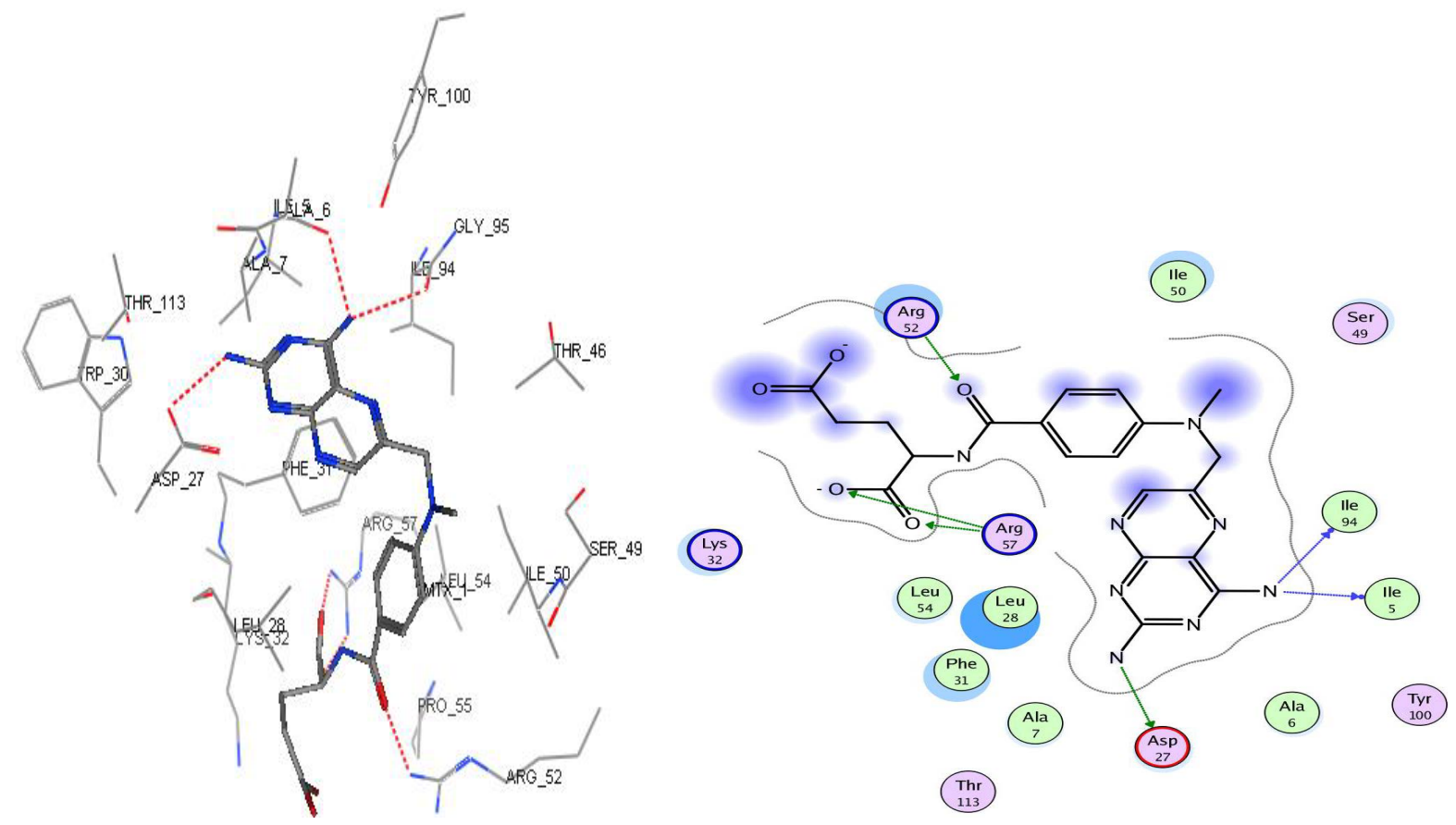

(a)
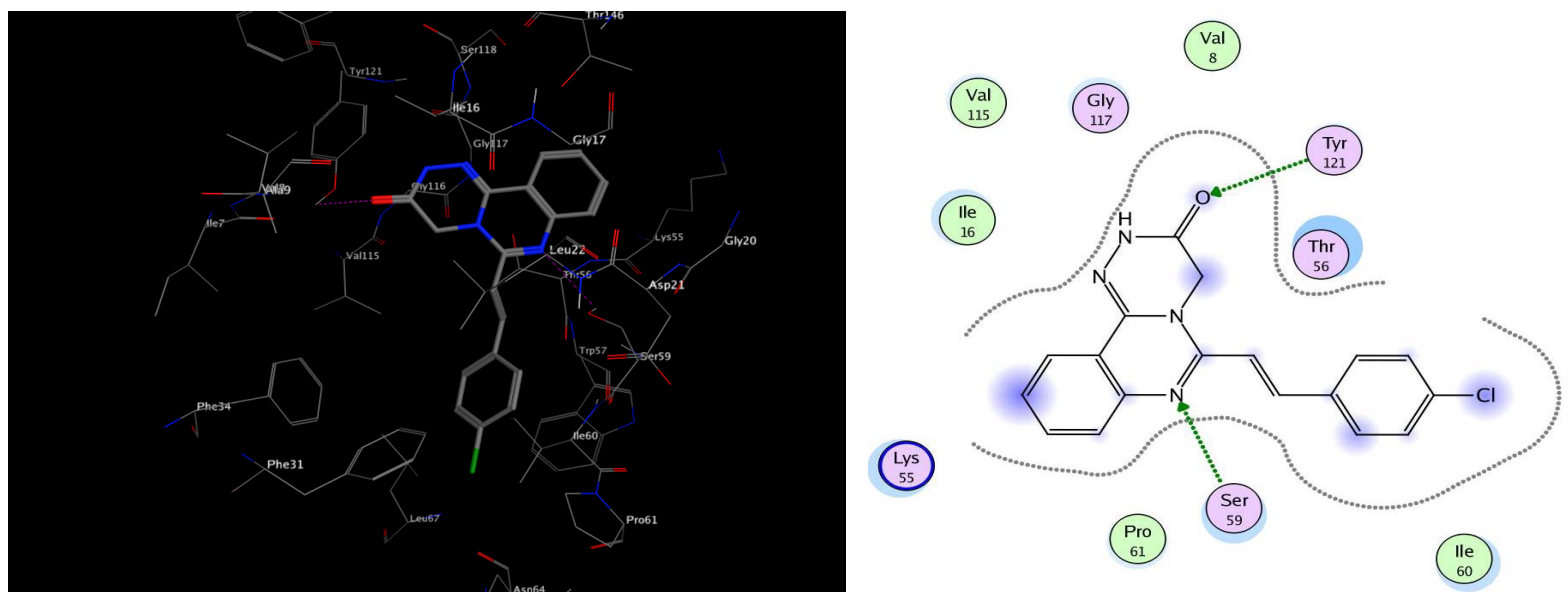

(b)

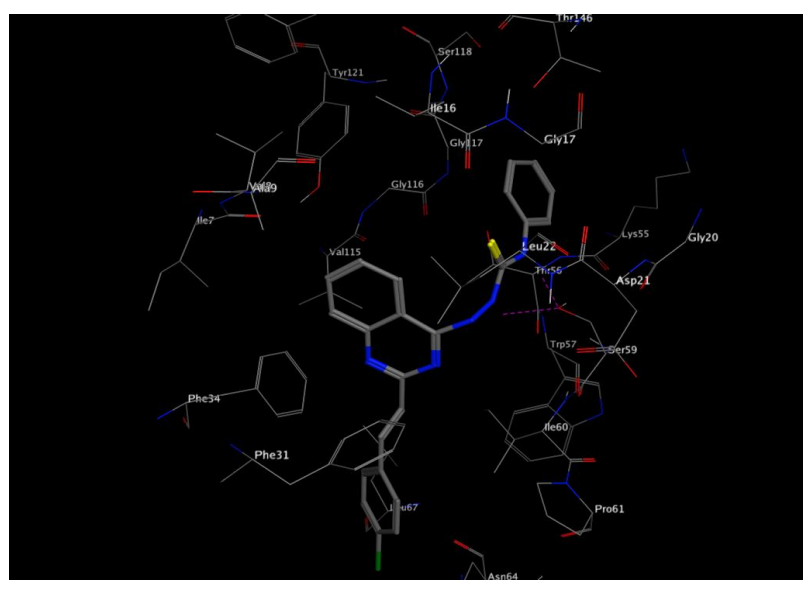

Ala

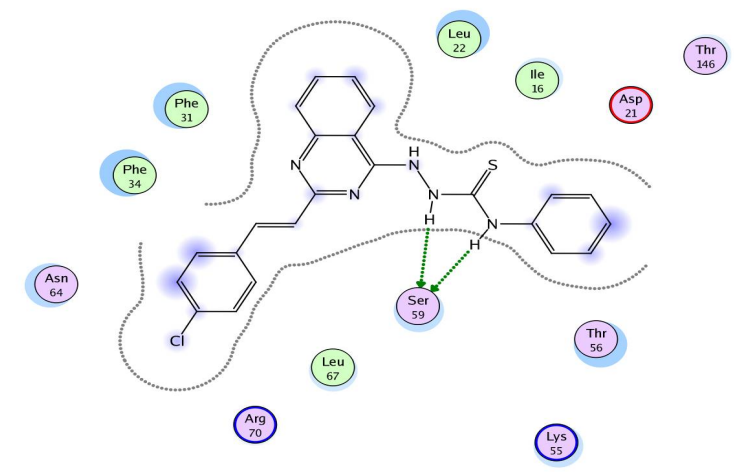

(c) 

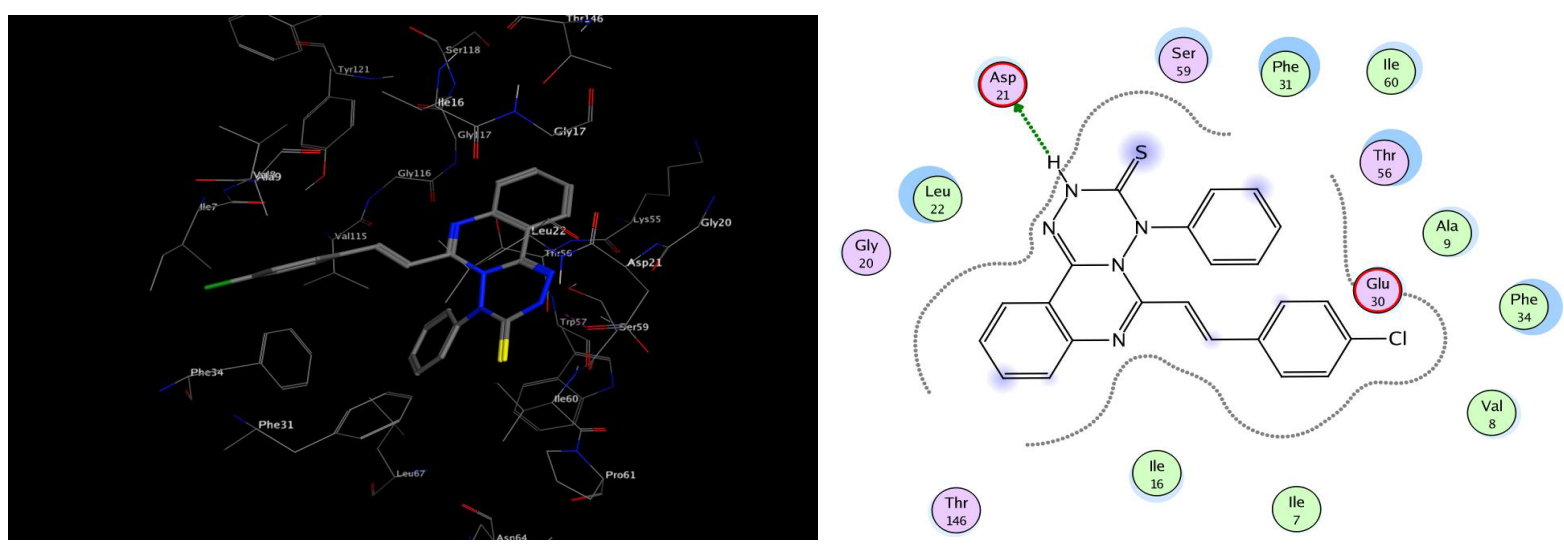

(d)
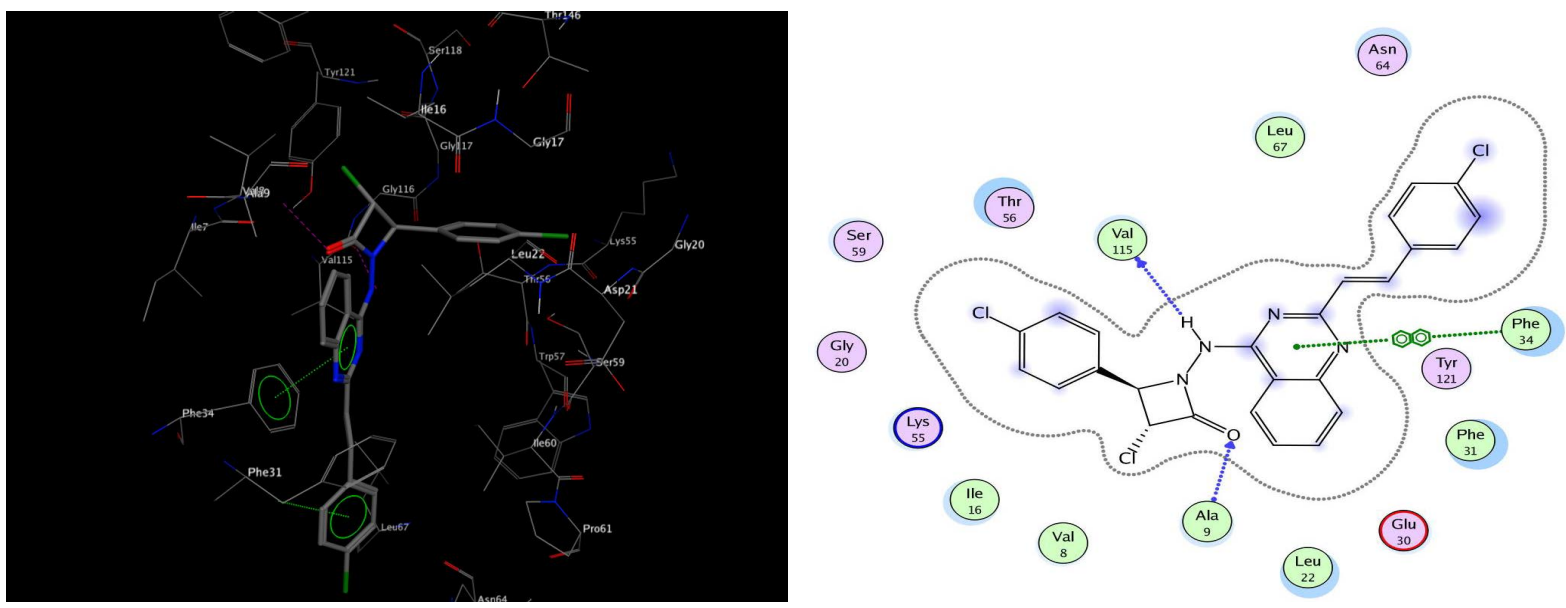

(e)
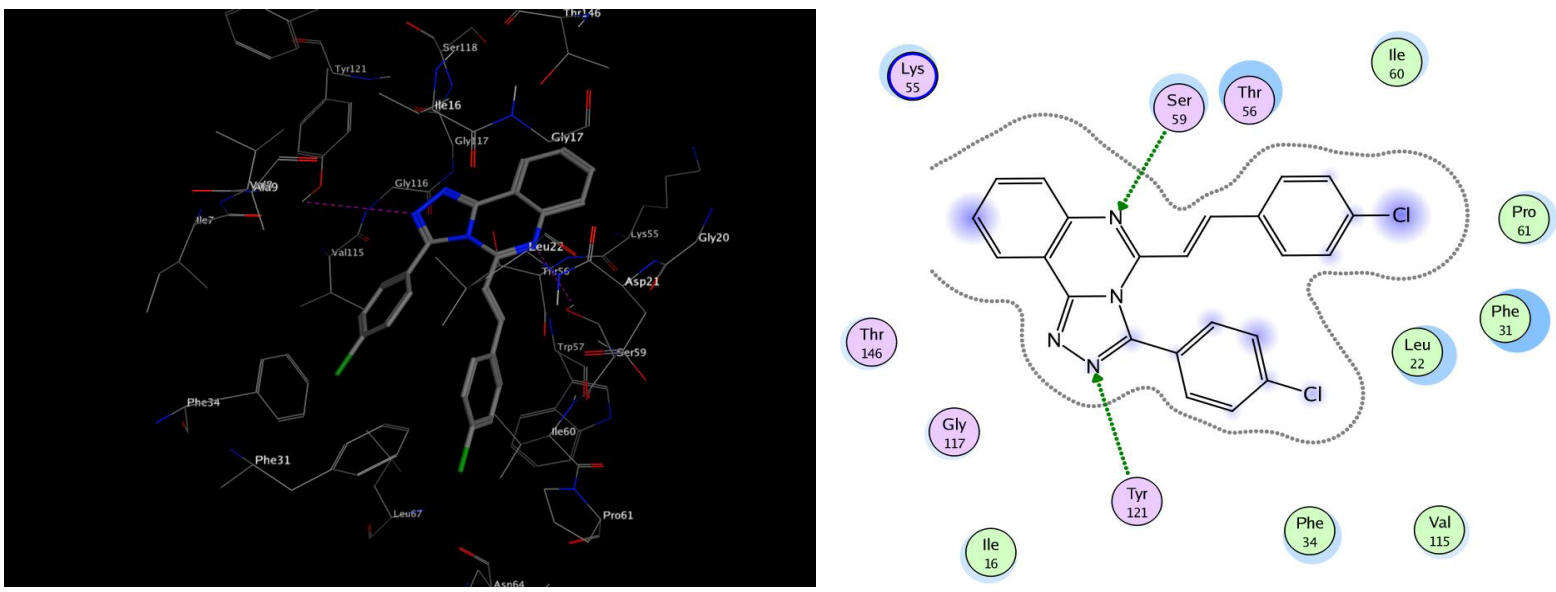

(f)

Figure 4. (a) Docking of MTX in the active site of DHFR; (b) Docking of compound 18 in the active site of DHFR; (c) Docking of compound 19 in the active site of DHFR; (d) Docking of compound 20 in the active site of DHFR; (e) Docking of compound 23 in the active site of DHFR; (f) Docking of compound 24 in the active site of DHFR.

The interaction of the carbonyl group oxygen as a hydrogen bond acceptor with the side chain residue Ala 9 (3.40 $\AA$ ) at a strength of $2.7 \%$, in addition to interaction of quinazoline- $\mathrm{C}_{4}-\mathrm{NH}$ function as a hydrogen bond donor with the side chain residue Val 115 (2.65 $\AA$ ) at a strength of 2.0\%, besides arene hydrophobic interaction between the center of quinazoline ring and amino acid residue Phe 34, in addition to many hydrophobic interac- 
tions among the 4-chlorostyryl moiety, azetidine- $\mathrm{C}_{4}$-4-chlorophenyl group as well as the quinazoline ring and the following amino acid residues: Val 8, Ala 9, Ile 16, Gly 20, Leu 22, Glu 30, Phe 31, Phe 34, Lys 55, Thr 56, Ser 59, Asn 64, Leu 67, Val 115 and Tyr 121 as shown in Figure 4(e).

6) Docking of compound $\mathbf{2 4}$ into DHFR active site revealed:

The interaction of quinazoline- $\mathrm{N}_{1}$ atom as a hydrogen bond acceptor with the side chain residue Ser 59 (3.00 $\AA$ ) at a strength of $5.6 \%$ as well as the interaction of triazole- $\mathrm{N}_{2}$ atom as a hydrogen bond acceptor with the side chain residue Tyr 121 (3.66 $\AA$ ) at a strength of $3.9 \%$, besides many hydrophobic interactions among the chlorine atom, quinazoline- $\mathrm{C}_{6}$ carbon, triazole- $\mathrm{C}_{3}$ carbon, in addition to triazole- $\mathrm{C}_{3}-4$-chlorophenyl moiety and the following amino acid residues: Ile 16, Leu 22, Phe 31, Phe 34, Lys 55, Thr 56, Ser 59, Ile 60, Pro 61, Val 115, Gly 117, and Tyr 146 as shown in Figure 4(f).

\section{Experimental}

\subsection{Chemistry}

All melting points were measured on Electro thermal LA 9000 SERIS, Digital Melting point Apparatus and are uncorrected. IR spectra (KBr) were recorded on FT-IR 200 spectrophotometer $\left(v \mathrm{~cm}^{-1}\right)$, pharmaceutical analytical unit, Faculty of Pharmacy, Al-Azhar University. ${ }^{1} \mathrm{H}-\mathrm{NMR}$ spectra were recorded in (DMSO-d $)_{6}$ at $300 \mathrm{MHz}$ on a Varian Gemini NMR spectrometer ( $\delta$ ppm) using TMS as an internal standard, Resarch Service Unit, Faculty of Science, Cairo University. Mass spectra were recorded on GC Ms-QP 5050A mass spectrometer at 70 eV and microanalytical data were performed on Elementar Vario EI III CHN analyzer at the microanalytical unit, in Regional center for Mycology and Biotechnology, Al-Azhar University. Thin layer chromatography was performed on precoated $(0.25 \mathrm{~mm})$ silica gel $\mathrm{GF}_{254}$ plates (E. Merck, Germany). Compounds were detected with $254 \mathrm{~nm}$ UV lamp.

\subsubsection{2-[2-(2-Chlorophenyl)-2-oxoethyl]quinazolin-4(3H)-one; 2}

A solution of compound 1 [36] (1.6 g, $0.01 \mathrm{~mol})$ in dry THF (20 mL) was added dropwise while stirring to a solution of 2-chlorobenzoyl chloride $(3.5 \mathrm{~g}, 2.8 \mathrm{~mL}, 0.02 \mathrm{~mol}$. $)$ in dry THF $(10 \mathrm{~mL})$ at $0^{\circ} \mathrm{C}$ and stirring was continued for $2 \mathrm{~h}$. The reaction mixture was further stirred for $4 \mathrm{~h}$ at room temperature then it was poured onto crushed ice. The solid obtained was filtered off, washed with water, dried and recrystallized from ethanol to yield compound 2.

White crystals, yield\%: $87 \%$, m.p.: $153^{\circ} \mathrm{C}-155^{\circ} \mathrm{C}$, IR $\left(\mathrm{KBr}, \mathrm{cm}^{-1}\right)$ : 3550 (br. OH); 3071 (C-H aromatic); 2973, 2817 (C-H aliphatic); $1693(\mathrm{C}=\mathrm{O}) ; 1574(\mathrm{C}=\mathrm{N}) ; 1473$ (C=C). ${ }^{1} \mathbf{H}-\mathbf{N M R}$ (DMSO-d ${ }_{6}, \delta$ ppm): 4.33 (s, $2 \mathrm{H}$, $\left.\mathrm{CH}_{2}\right) ; 7.51$ - $7.59\left(\mathrm{~m}, 4 \mathrm{H}\right.$, quinazoline- $\left.\mathrm{C}_{5,6,7,8} \mathrm{H}\right) ; 7.73\left(\mathrm{~s}, 1 \mathrm{H}, \mathrm{NH}, \mathrm{D}_{2} \mathrm{O}\right.$ exchangeable); $7.74-7.86(\mathrm{~m}, 4 \mathrm{H}$, 2-Cl- $\left.\mathrm{C}_{6} \mathrm{H}_{4}-\mathrm{C}_{3,4,5,6}-\mathrm{H}\right) ; \mathrm{MS} \mathrm{m} / \mathrm{z}$ (relative intensity \%): $298\left(\mathrm{M}^{+}\right.$, 2.90); 48 (100). Anal. Form: $\mathrm{C}_{16} \mathrm{H}_{11} \mathrm{ClN}_{2} \mathrm{O}_{2}$ (298.5). Calcd. (\%): C, 64.32; H, 3.68; N, 9.38; Found (\%): C, 64.37; H, 3.75; N, 9.30.

\subsubsection{H-Quinolino[2,1-b]quinazolin-5,12-(6H)-dione; 3}

A solution of compound 1 (1.6 g, $0.01 \mathrm{~mol})$ in dry THF $(20 \mathrm{~mL})$ was added dropwise while stirring to a solution of 2-chlorobenzoyl chloride $(3.5 \mathrm{~g}, 2.8 \mathrm{~mL}, 0.02 \mathrm{~mol})$ in dry THF $(10 \mathrm{~mL})$ at $0^{\circ} \mathrm{C}$ and stirring was continued for $2 \mathrm{~h}$. The reaction mixture was refluxed for another $2 \mathrm{~h}$ and the obtained product was filtered, washed with THF, dried and recrystallized from ethanol to give compound 3.

White crystals, yield \%: $75 \%$, m.p.: $300^{\circ} \mathrm{C}-302^{\circ} \mathrm{C}$, IR $\left(\mathrm{KBr}, \mathrm{cm}^{-1}\right.$ ): 3000 (C-H aromatic); 1708, 1690 (two $\mathrm{C}=\mathrm{O}) ; 1569(\mathrm{C}=\mathrm{N}) ; 1478(\mathrm{C}=\mathrm{C}) .{ }^{1} \mathbf{H}-\mathrm{NMR}\left(\mathrm{DMSO}_{-}, \delta \mathrm{ppm}\right): 2.49$ (s, $\left.2 \mathrm{H}, \underline{\mathrm{CH}}_{2}-\mathrm{C}=\mathrm{O}\right) ; 7.51$ (d, $2 \mathrm{H}, \mathrm{J}=8.3 \mathrm{~Hz}$ quinazolin- $\left.\mathrm{C}_{6,7}-\mathrm{H}\right) ; 7.61-7.69\left(\mathrm{~m}, 2 \mathrm{H}\right.$, quinoline- $\left.\mathrm{C}_{6,7}-\mathrm{H}\right) ; 7.81\left(\mathrm{~d}, 1 \mathrm{H}, \mathrm{J}=8.3 \mathrm{~Hz}\right.$, quinazoline- $\left.\mathrm{C}_{5}-\mathrm{H}\right) ; 7.91(\mathrm{~d}, 1 \mathrm{H}$, $\mathrm{J}=7.2 \mathrm{~Hz}$, quinoline- $\left.\mathrm{C}_{5}-\mathrm{H}\right) ; 7.96\left(\mathrm{~d}, 1 \mathrm{H}, \mathrm{J}=7.2 \mathrm{~Hz}\right.$, quinoline- $\left.\mathrm{C}_{8}-\mathrm{H}\right) ; 8.15(\mathrm{~d}, 1 \mathrm{H}, \mathrm{J}=8.3 \mathrm{~Hz}$, quinazoline $-\mathrm{C}_{8}-\mathrm{H}$ ). MS m/z (relative intensity \%): 262 ( $\mathrm{M}^{+}$, 3.04); 74 (100). Anal. Form: $\mathrm{C}_{16} \mathrm{H}_{10} \mathrm{~N}_{2} \mathrm{O}_{2}$ (262). Calcd. (\%): C, 73.27; H, 3.84, N, 10.68; Found (\%): C, 73.25; H, 3.89; N, 10.60.

\subsubsection{H-Quinolino[2,1-b]quinazolin-12-one; 4}

Equimolar amounts of compound 1 (1.6 g, $0.01 \mathrm{~mol})$ and 2-chlorobenzaldehyde $(1.4 \mathrm{~g}, 1.1 \mathrm{~mL}, 0.01 \mathrm{~mol})$ were refluxed in glacial acetic acid $(30 \mathrm{~mL})$ in presence of anhydrous sodium acetate $(2 \mathrm{~g}, 0.02 \mathrm{~mol})$ for $8 \mathrm{~h}$. The reaction mixture was allowed to cool then poured onto crushed ice. The obtained solid was filtered off, washed with water and recrystallized from ethanol to yield compound 4. 
White crystals, yield \%: 88\%, m.p.: $253^{\circ} \mathrm{C}-255^{\circ} \mathrm{C}$, IR $\left(\mathrm{KBr}, \mathrm{cm}^{-1}\right): 3058$ (C-H aromatic); 1681 (C=O); 1568 $(\mathrm{C}=\mathrm{N}) ; 1511(\mathrm{C}=\mathrm{C}) .{ }^{1} \mathrm{H}-\mathrm{NMR}$ (DMSO-d $\left.\mathrm{d}_{6}, \delta \mathrm{ppm}\right)$ : 7.01 (s, $1 \mathrm{H}$, quinoline- $\left.\mathrm{C}_{4}-\mathrm{H}\right) ; 7.07$ (s, $1 \mathrm{H}$, quinoline- $\left.\mathrm{C}_{3}-\mathrm{H}\right)$; $7.43-7.58\left(\mathrm{~m}, 3 \mathrm{H}\right.$, quinoline- $\left.\mathrm{C}_{5,6,7}-\mathrm{H}\right) ; 7.71\left(\mathrm{~d}, 2 \mathrm{H}, \mathrm{J}=7.8 \mathrm{~Hz}\right.$, quinazoline- $\left.\mathrm{C}_{6,7}-\mathrm{H}\right) ; 7.80-7.86(\mathrm{~m}, 2 \mathrm{H}$, quinoline- $\mathrm{C}_{8}-\mathrm{H} \&$ quinazoline- $\left.\mathrm{C}_{5}-\mathrm{H}\right) ; 8.11\left(\mathrm{~d}, 1 \mathrm{H}, \mathrm{J}=7.8 \mathrm{~Hz}\right.$, quinazoline- $\left.\mathrm{C}_{8}-\mathrm{H}\right) . \mathbf{M S} \mathrm{m} / \mathrm{z}$ (relative intensity \%): $246\left(\mathrm{M}^{+}, 100\right)$. Anal. Form: $\mathrm{C}_{16} \mathrm{H}_{10} \mathrm{~N}_{2} \mathrm{O}$ (246). Calcd. (\%): C, 78.03; H, 4.09; N, 11.38; Found(\%): C, 78.11; H, 4.12; $\mathrm{N}, 11.30$.

\subsubsection{Pyrrolo[2,1-b]quinazolin-2,9(1H, 3H)-dione; 5}

A solution of compound $1(1.6 \mathrm{~g}, 0.01 \mathrm{~mol})$ in dry THF $(20 \mathrm{~mL})$ was added dropwise while stirring to a solution of chloroacetyl chloride (2.26 g, $1.6 \mathrm{~mL}, 0.02 \mathrm{~mol})$ in dry THF $(10 \mathrm{~mL})$ at $0^{\circ} \mathrm{C}$ and stirring was continued for $2 \mathrm{~h}$. The reaction mixture was further stirred for $4 \mathrm{~h}$ at room temperature then the excess solvent was evaporated. The reaction mixture was cooled and poured onto crushed ice. The solid obtained was filtered off, washed with water, dried and recrystallized from ethanol.

White crystals, yield \%: 65\%, m.p.: $313^{\circ} \mathrm{C}-315^{\circ} \mathrm{C}$, IR $\left(\mathrm{KBr}, \mathrm{cm}^{-1}\right)$ : 3034 (C-H aromatic); 2819 (C-H aliphatic); 1704, 1669 (two C=O); $1561(\mathrm{C}=\mathrm{N}) ; 1479$ (C=C). ${ }^{1} \mathbf{H}-\mathrm{NMR}\left(\mathrm{DMSO}_{6}, \delta\right.$ ppm): 2.08 (s, 2H, pyrrolo$\left.\mathrm{C}_{3}-\mathrm{H}\right)$; 2.49 (s, 2H, pyrrolo- $\left.\mathrm{C}_{1}-\mathrm{H}\right) ; 7.60$ - $7.65\left(\mathrm{~m}, 1 \mathrm{H}, \mathrm{C}_{7}-\mathrm{H}\right) ; 7.76$ (d, 1H, J = $\left.8 \mathrm{~Hz}, \mathrm{C}_{6}-\mathrm{H}\right) ; 7.91$ - 7.96 (m, 1H, $\mathrm{C}_{5}-\mathrm{H}$ ); 8.15 (d, $\left.1 \mathrm{H}, \mathrm{J}=8 \mathrm{~Hz}, \mathrm{C}_{8}-\mathrm{H}\right)$. MS m/z (relative intensity \%): $200\left(\mathrm{M}^{+}, 1.99\right) ; 62$ (100). Anal. Form: $\mathrm{C}_{11} \mathrm{H}_{8} \mathrm{~N}_{2} \mathrm{O}_{2}$ (200). Calcd. (\%): C, 66.00; H, 4.03. Found (\%): C, 65.98; H, 4.08.

\subsubsection{2-(4-Chlorostyryl)quinazolin-4(3H)-one; 6}

Equimolar amounts of compound 1 (1.6 g, $1 \mathrm{~mol}$ ) and 4-chlorobenzaldehyde (1.4 g, $1 \mathrm{~mol})$ were refluxed in glacial acetic acid $(30 \mathrm{~mL})$ for $8 \mathrm{~h}$ in presence of anhydrous sodium acetate $(2 \mathrm{~g}, 0.02 \mathrm{~mol})$. The reaction mixture was allowed to cool then poured onto crushed ice. The obtained product was filtered, washed with water and recrystallized from ethanol.

White crystals, yield \%: $85 \%$, m.p: $302^{\circ} \mathrm{C}-305^{\circ} \mathrm{C}[41]$.

\subsubsection{4-Chloro-2-(4-chlorostyryl)quinazoline; 7}

Compound 6 ( $3.5 \mathrm{~g}, 0.123 \mathrm{~mol}$ ) was refluxed in excess phosphorous oxychloride (5 mL) for $14 \mathrm{~h}$ and in presence of a catalytic amount of triethylamine (3 - 5 drops). The reaction mixture was allowed to cool then poured onto crushed ice. The obtained solid was collected.

Yellowish brown, yield \%: $82 \%$, m.p.: $268^{\circ} \mathrm{C}-270^{\circ} \mathrm{C}$ [41].

\subsubsection{4-Amino-2-(4-chlorostyryl)quinazoline; 8}

A mixture of compound 7 (3.2 g, $0.1 \mathrm{~mol})$ and ammonium acetate $(2.3 \mathrm{~g}, 0.3 \mathrm{~mol})$ was refluxed in pyridine (30 $\mathrm{mL}$ ) for $24 \mathrm{~h}$. The reaction mixture was allowed to cool then poured onto crushed ice. The obtained solid was filtered off, dried and recrystallized from acetone.

Brown crystals, yield\%: 58\%, m.p.: $318^{\circ} \mathrm{C}-320^{\circ} \mathrm{C}$, IR $\left(\mathrm{KBr}, \mathrm{cm}^{-1}\right)$ : 3251,3142 ( $\left.\mathrm{NH}_{2}\right)$; 3055 (C-H aromatic); $1600(\mathrm{C}=\mathrm{N}) ; 1596(\mathrm{C}=\mathrm{C}) .{ }^{1} \mathrm{H}-\mathrm{NMR}$ (DMSO-d $\left.\mathrm{D}_{6}, \delta \mathrm{ppm}\right): 4.20$ (s, 2H, $\mathrm{NH}_{2}, \mathrm{D}_{2} \mathrm{O}$ exchangeable); 7.01 (s, $1 \mathrm{H}$, $\left.\mathrm{CH}=\underline{\mathrm{CH}}-4-\mathrm{Cl}_{-} \mathrm{C}_{6} \mathrm{H}_{4}\right) ; 7.06\left(\mathrm{~s}, 1 \mathrm{H}, \underline{\mathrm{CH}}=\mathrm{CH}-4-\mathrm{Cl}-\mathrm{C}_{6} \mathrm{H}_{4}\right) ; 7.52\left(\mathrm{~d}, 1 \mathrm{H}, \mathrm{J}=6.9 \mathrm{~Hz}\right.$, quinazoline- $\left.\mathrm{C}_{5}-\mathrm{H}\right) ; 7.55(\mathrm{~d}, 1 \mathrm{H}$, $\mathrm{J}=6.9 \mathrm{~Hz}$, quinazoline- $\left.\mathrm{C}_{8}-\mathrm{H}\right) ; 7.71\left(\mathrm{~d}, 2 \mathrm{H}, \mathrm{J}=8.1 \mathrm{~Hz}, 4-\mathrm{Cl}_{-} \mathrm{C}_{6} \mathrm{H}_{4}-\mathrm{C}_{2,6}-\mathrm{H}\right) ; 7.83-7.86(\mathrm{~m}, 1 \mathrm{H}$, quinazoline- $\left.\mathrm{C}_{6}-\mathrm{H}\right)$; 7.87-7.97 (m, $1 \mathrm{H}$, quinazoline- $\left.\mathrm{C}_{7}-\mathrm{H}\right) ; 8.14\left(\mathrm{~d}, 2 \mathrm{H}, \mathrm{J}=8.1 \mathrm{~Hz}, 4-\mathrm{Cl}_{-} \mathrm{C}_{6} \mathrm{H}_{4}-\mathrm{C}_{3,5}-\mathrm{H}\right)$. Anal. Form: $\mathrm{C}_{16} \mathrm{H}_{12} \mathrm{ClN}_{3}$ (281.5). Calcd. (\%): C, 68.20; H, 4.26; N, 14.92 Found(\%): C, 68.19; H, 4.43; N, 14.64.

\subsubsection{2-(4-Chlorostyryl)-4-hydrazinylquinazoline; 9}

A mixture of compound 7 (3.2 g, 1mol) and hydrazine hydrate $99 \%$ (0.5 g, $0.5 \mathrm{~mL}, 5 \mathrm{~mol})$ (1:5) was refluxed in absolute ethanol ( $30 \mathrm{~mL}$ ) for $8 \mathrm{~h}$. The reaction mixture was allowed to cool and poured on crushed ice. The obtained solid was filtered, dried and recrystallized from acetone/ethanol.

Yellow crystals, yield \%: 42\%, m.p.: $180^{\circ} \mathrm{C}-182^{\circ} \mathrm{C}$, IR $\left(\mathrm{KBr}, \mathrm{cm}^{-1}\right)$ : 3430, 3310, $3200\left(\mathrm{NH}_{2}, \mathrm{NH}\right) ; 3050$ (C-H aromatic); 2920 (C-H aliphatic); 1550 (C=N); 1495 (C=C). ${ }^{1}$ H-NMR (DMSO-d $\mathrm{d}_{6}, \delta$ ppm): 4.15 (s, 2H, $\mathrm{NH}_{2}, \mathrm{D}_{2} \mathrm{O}$ exchangeable); 6.99 (s, $\left.1 \mathrm{H}, \mathrm{CH}=\underline{\mathrm{CH}}-4-\mathrm{Cl}_{-} \mathrm{C}_{6} \mathrm{H}_{4}\right) ; 7.04$ (s, $\left.1 \mathrm{H}, \underline{\mathrm{CH}}=\mathrm{CH}-4-\mathrm{Cl}_{-} \mathrm{C}_{6} \mathrm{H}_{4}\right) ; 7.25$ - 7.36 (m, $1 \mathrm{H}$, quinazoline- $\left.\mathrm{C}_{5}-\mathrm{H}\right) ; 7.44-7.54\left(\mathrm{~m}, 1 \mathrm{H}\right.$, quinazoline- $\left.\mathrm{C}_{6}-\mathrm{H}\right) ; 7.60-7.70\left(\mathrm{~m}, 1 \mathrm{H}\right.$, quinazoline- $\left.\mathrm{C}_{7}-\mathrm{H}\right) ; 7.74(\mathrm{~d}$, $1 \mathrm{H}, \mathrm{J}=6.9 \mathrm{~Hz}$, quinazoline- $\left.\mathrm{C}_{8}-\mathrm{H}\right) ; 7.80\left(\mathrm{~d}, 2 \mathrm{H}, \mathrm{J}=8.4 \mathrm{~Hz}, 4-\mathrm{Cl}_{-} \mathrm{C}_{6} \mathrm{H}_{4}-\mathrm{C}_{2}, 6-\mathrm{H}\right) ; 8.11$ (d, 2H, J = 8.4 Hz, 4-Cl$-\mathrm{C}_{6} \mathrm{H}_{4}-\mathrm{C}_{3,5}-\mathrm{H}$ ); 12.26 (s, $1 \mathrm{H}, \mathrm{NH}, \mathrm{D}_{2} \mathrm{O}$ exchangeable). Anal. Form: $\mathrm{C}_{16} \mathrm{H}_{13} \mathrm{ClN}_{4}$ (296.5) Calcd. (\%): C, 64.75; H, 
4.38; N, 18.86; Found (\%): C, 64.80; H, 4.41; N, 18.64.

\subsubsection{1-[2-(4-Chlorostyryl)quinazolin-4-yl]-3-phenylthiourea; 10}

A solution of compound $8(2.8 \mathrm{~g}, 0.01 \mathrm{~mol})$ in pyridine $(30 \mathrm{~mL})$ was treated with an equimolar amount of phenyl isothiocyanate $(1.4 \mathrm{~g}, 1.2 \mathrm{~mL}, 0.01 \mathrm{~mol})$. The reaction mixture was heated under reflux for $18 \mathrm{~h}$, then cooled, poured onto crushed ice and acidified with $10 \%$ hydrochloric acid. The solid product obtained was filtered off, washed with water and recrystallized from ethanol.

Brown crystals, yield \%: 78\%, m.p.: $243^{\circ} \mathrm{C}-245^{\circ} \mathrm{C}$, IR $\left(\mathrm{KBr}, \mathrm{cm}^{-1}\right)$ : 3433, 3184 (NH); 3046 (C-H aromatic); 2921 (C-H aliphatic); 1603 (C=N); 1493 (C=C); 1572, 1293, 1141, 964 (N-C=S). ${ }^{1}$ H-NMR (DMSO-d $\mathrm{d}_{6}, \delta$ ppm): 6.99 (s, $\left.1 \mathrm{H}, \mathrm{CH}=\underline{\mathrm{CH}}-4-\mathrm{Cl}-\mathrm{C}_{6} \mathrm{H}_{4}\right) ; 7.04\left(\mathrm{~s}, 1 \mathrm{H}, \underline{\mathrm{CH}}=\mathrm{CH}-4-\mathrm{Cl}_{-} \mathrm{C}_{6} \mathrm{H}_{4}\right) ; 7.48\left(\mathrm{~d}, 2 \mathrm{H}, \mathrm{J}=7.5 \mathrm{~Hz}\right.$, quinazoline- $\left.\mathrm{C}_{6,7}-\mathrm{H}\right)$; $7.52\left(\mathrm{~d}, 2 \mathrm{H}, \mathrm{J}=8.6 \mathrm{~Hz}, 4-\mathrm{Cl}_{-} \mathrm{C}_{6} \mathrm{H}_{4}-\mathrm{C}_{2,6}-\mathrm{H}\right) ; 7.69$ (d, 2H, J = 8.6Hz, 4-Cl- $\left.\mathrm{C}_{6} \mathrm{H}_{4}-\mathrm{C}_{3}, 5-\mathrm{H}\right) ; 7.79-7.83$ (m, 5H, $\mathrm{C}_{6} \mathrm{H}_{5}$ ); 7.96 (s, $1 \mathrm{H}, \mathrm{NH}-\mathrm{C}_{6} \mathrm{H}_{5}, \mathrm{D}_{2} \mathrm{O}$ exchangeable); 8.11 (d, $2 \mathrm{H}, \mathrm{J}=7.5 \mathrm{~Hz}$, quinazoline- $\left.\mathrm{C}_{5,8}-\mathrm{H}\right) ; 12.31$ (s, $1 \mathrm{H}$, NH-CS-NH- $\mathrm{C}_{6} \mathrm{H}_{5}, \mathrm{D}_{2} \mathrm{O}$ exchangeable). Anal. Form: $\mathrm{C}_{23} \mathrm{H}_{17} \mathrm{ClN}_{4} \mathrm{~S}$ (416.5) Calcd. (\%): C, 66.26; H, 4.08; N, 13.44; S, 7.68. Found (\%): C, 66.28; H, 4.16; N, 13.62; S, 7.74.

\subsubsection{General Procedure for Synthesis of Compounds 11 \& 12}

A solution of compound $\mathbf{1 0}(0.4 \mathrm{~g}, 0.01 \mathrm{~mol})$ in ethanol $(30 \mathrm{~mL})$ and in presence of a catalytic amount of sodium acetate $(1 \mathrm{~g}, 0.01 \mathrm{~mol})$ was heated under reflux for $6 \mathrm{~h}$ with an equimolar amount of the appropriate chloro compound namely; ethyl chloroacetate $(0.6 \mathrm{~g}, 0.5 \mathrm{~mL}, 0.01 \mathrm{~mol})$ or phenacyl chloride ( $0.5 \mathrm{~g}, 0.01 \mathrm{~mol})$. The solid obtained after cooling the reaction mixture was filtered off and washed with water to yield compounds $\mathbf{1 1}$ and 12 respectively.

\section{1) 2-[2-(4-Chlorostyryl)quinazolin-4-ylimino]-3-phenylthiazolidin-4-one; 11}

Recrystallized from ethanol, buff crystals, yield \%: $43 \%$, m.p.: $283^{\circ} \mathrm{C}-285^{\circ} \mathrm{C}, \mathrm{IR}\left(\mathrm{KBr}, \mathrm{cm}^{-1}\right): 3045(\mathrm{C}-\mathrm{H}$ aromatic); 2923 (C-H aliphatic); 1665 (C=O); $1603(\mathrm{C}=\mathrm{N}) ; 1571(\mathrm{C}=\mathrm{C}) ; 1342,1084$ (C-S-C). ${ }^{1} \mathbf{H}-\mathbf{N M R}$

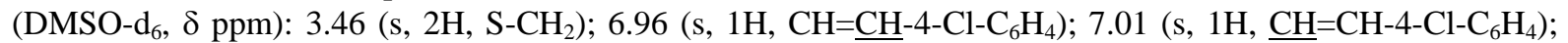
7.49 (d, $\left.2 \mathrm{H}, \mathrm{J}=8.4 \mathrm{~Hz}, 4-\mathrm{Cl}_{-} \mathrm{C}_{6} \mathrm{H}_{4}-\mathrm{C}_{2,6}-\mathrm{H}\right) ; 7.69$ (d, 2H, J = $\left.8.4 \mathrm{~Hz}, 4-\mathrm{Cl}_{-} \mathrm{C}_{6} \mathrm{H}_{4}-\mathrm{C}_{3,5}-\mathrm{H}\right) ; 7.77$ - 7.82 (m, 5H, $\left.\mathrm{C}_{6} \mathrm{H}_{5}\right) ; 7.85$ - $7.90\left(\mathrm{~m}, 3 \mathrm{H}\right.$, quinazoline- $\left.\mathrm{C}_{5,6,7}-\mathrm{H}\right) ; 8.09\left(\mathrm{~d}, 1 \mathrm{H}, \mathrm{J}=7.5 \mathrm{~Hz}\right.$, quinazoline- $\left.\mathrm{C}_{8}-\mathrm{H}\right)$. MS m/z (relative intensity \%): 456 (M+1 1.92); 62 (100). Anal. Form: $\mathrm{C}_{25} \mathrm{H}_{17} \mathrm{ClN}_{4} \mathrm{OS}$ (456.5) Calcd. (\%): C, 65.71; H, 3.72; N, 12.26; S, 7.00. Found (\%): C, 65.74; H, 3.82; N, 12.39; S, 7.10.

\section{2) 2-(4-Chlorostyryl)- $N$-(3,4-diphenylthiazol-2(3H)ylidene)quinazolin-4-amine; 12}

Recrystallized from ethanol, brown crystals, yield \%: $45 \%$, m.p.: $273^{\circ} \mathrm{C}-275^{\circ} \mathrm{C}, \mathbf{I R}\left(\mathrm{KBr}, \mathrm{cm}^{-1}\right): 3000(\mathrm{C}-\mathrm{H}$ aromatic); 2927 (C-H aliphatic); 1615 (C=N); 1548 (C=C); 1380, 1040 (C-S-C). ${ }^{1}$ H-NMR (DMSO-d $\mathrm{d}_{6}, \delta$ ppm): 6.99 (s, $\left.1 \mathrm{H}, \mathrm{CH}=\mathrm{CH}-4-\mathrm{Cl}_{-} \mathrm{C}_{6} \mathrm{H}_{4}\right) ; 7.05$ (s, $\left.1 \mathrm{H}, \underline{\mathrm{CH}}=\mathrm{CH}-4-\mathrm{Cl}_{-} \mathrm{C}_{6} \mathrm{H}_{4}\right) ; 7.49$ (s, $1 \mathrm{H}, \mathrm{CH}$-thiazole); 7.52 (d, 2H, J = 8.4Hz, 4-Cl- $\left.\mathrm{C}_{6} \mathrm{H}_{4}-\mathrm{C}_{2,6}-\mathrm{H}\right) ; 7.68$ - 7.79 (m, $10 \mathrm{H}$, two $\left.\mathrm{C}_{6} \mathrm{H}_{5}\right) ; 7.83\left(\mathrm{~d}, 2 \mathrm{H}, \mathrm{J}=7.8 \mathrm{~Hz}\right.$, quinazoline- $\left.\mathrm{C}_{6,7}-\mathrm{H}\right) ; 7.91$ $7.96\left(\mathrm{~m}, 2 \mathrm{H}, 4-\mathrm{Cl}_{-} \mathrm{C}_{6} \mathrm{H}_{4}-\mathrm{C}_{3,5}-\mathrm{H}\right) ; 8.12\left(\mathrm{~d}, 2 \mathrm{H}, \mathrm{J}=7.8 \mathrm{~Hz}\right.$, quinazoline- $\left.\mathrm{C}_{5,8}-\mathrm{H}\right)$. MS m/z (relative intensity \%): 516 ( $\mathrm{M}^{+}$, 1.26), 117 (100). Anal. Form: $\mathrm{C}_{31} \mathrm{H}_{21} \mathrm{ClN}_{4} \mathrm{~S}$ (516.5). Calcd. (\%): C,72.02; H, 4.06; N, 10.84; S, 6.19. Found (\%): C, 72.07; H, 4.13; N, 10.72; S, 6.18.

\subsubsection{2-(4-Chlorostyryl)-N-(4-methyl-3-phenylthiazol-2(3H)-ylidene)quinazolin-4-amine; 13}

An equimolar mixture of compound $10(0.4 \mathrm{~g}, 0.01 \mathrm{~mol})$ and chloroacetone $(0.09 \mathrm{~g}, 0.1 \mathrm{~mL}, 0.01 \mathrm{~mol})$ was fused at $120^{\circ} \mathrm{C}$ for $24 \mathrm{~h}$. The reaction mixture was triturated with ethanol. The obtained product was filtered off then washed with several solvents.

Black crystals, yield\%: 52\%, m.p.; >360 ${ }^{\circ} \mathrm{C}$, IR ( $\mathrm{KBr}, \mathrm{cm}^{-1}$ ): 3070 (C-H aromatic); 2925 (C-H aliphatic); 1600 $(\mathrm{C}=\mathrm{N}) ; 1490(\mathrm{C}=\mathrm{C}) ; 1375,1186$ (C-S-C). MS m/z (relative intensity \%): $454\left(\mathrm{M}^{+}, 1.06\right), 53$ (100). Anal. Form: $\mathrm{C}_{26} \mathrm{H}_{19} \mathrm{ClN}_{4} \mathrm{~S}$ (454.5). Calcd. (\%): C, 68.64; H, 4.18; N, 12.32; S, 7.04. Found (\%): C, 68.70; H, 4.23; N, 12.39; $\mathrm{S}, 7.12$.

\subsubsection{General Procedure for Synthesis of Compounds 14 \& 15}

An equimolar mixture of compound 8 (1.4 g, $0.01 \mathrm{~mol})$ and phenacyl chloride $(0.8 \mathrm{~g}, 0.01 \mathrm{~mol})$ in ethanol (30 $\mathrm{mL}$ ) was refluxed for $18 \mathrm{~h}$. The reaction mixture was then concentrated, allowed to cool and the solid product obtained was filtered off to yield compound $\mathbf{1 4}$. The filtrate was poured onto crushed ice and the obtained solid was collected to give compound 15.

1) 4-Amino-2-(4-chlorostyryl)-3-(2-oxo-2-phenylethyl)quinazolin-3-ium chloride; 14 
Recrystallized from ethanol, brown crystals, yield\%: 64\%, m.p.: $278^{\circ} \mathrm{C}-280^{\circ} \mathrm{C}$, IR $\left(\mathrm{KBr}, \mathrm{cm}^{-1}\right): 3433\left(\mathrm{NH}_{2}\right)$; 3048 (C-H aromatic); 2921 (C-H aliphatic); $1672(\mathrm{C}=\mathrm{O}) ; 1582(\mathrm{C}=\mathrm{N}) ; 1460(\mathrm{C}=\mathrm{C}) .{ }^{1} \mathbf{H}-\mathrm{NMR}$ (DMSO-d 6 , $\delta$ ppm): 3.63 (s, $\left.2 \mathrm{H}, \mathrm{CH}_{2}\right) ; 5.18$ (s, $2 \mathrm{H}, \mathrm{NH}_{2}, \mathrm{D}_{2} \mathrm{O}$ exchangeable); 7.00 (s, $\left.1 \mathrm{H}, \mathrm{CH}=\mathrm{CH}-4-\mathrm{Cl}_{-} \mathrm{C}_{6} \mathrm{H}_{4}\right) ; 7.05$ (s, $1 \mathrm{H}$, $\left.\underline{\mathrm{CH}}=\mathrm{CH}-4-\mathrm{Cl}_{-} \mathrm{C}_{6} \mathrm{H}_{4}\right) ; 7.52\left(\mathrm{~d}, 1 \mathrm{H}, \mathrm{J}=7.2 \mathrm{~Hz}\right.$, quinazoline- $\left.\mathrm{C}_{5}-\mathrm{H}\right) ; 7.59$ - $7.74\left(\mathrm{~m}, 5 \mathrm{H}, \mathrm{C}_{6} \mathrm{H}_{5}\right) ; 7.77-7.84(\mathrm{~m}, 2 \mathrm{H}$, quinazoline- $\left.\mathrm{C}_{6,7}-\mathrm{H}\right) ; 8.06\left(\mathrm{~d}, 2 \mathrm{H}, \mathrm{J}=7.5 \mathrm{~Hz}, 4-\mathrm{Cl}-\mathrm{C}_{6} \mathrm{H}_{4}-\mathrm{C}_{2,6}-\mathrm{H}\right) ; 8.07$ - $8.10\left(\mathrm{~m}, 2 \mathrm{H}, 4-\mathrm{Cl}_{-} \mathrm{C}_{6} \mathrm{H}_{4}-\mathrm{C}_{3,5}-\mathrm{H}\right)$; 8.13 (s, $1 \mathrm{H}$, quinazoline- $\mathrm{C}_{8}-\mathrm{H}$ ); 12.33 (s, $1 \mathrm{H}, \mathrm{OH}, \mathrm{D}_{2}$ Oexchangeable). Anal.Form: $\mathrm{C}_{24} \mathrm{H}_{19} \mathrm{Cl}_{2} \mathrm{~N}_{3} \mathrm{O}$ (436) Calcd. (\%): C, 66.05; H, 4.35; N, 9.63. Found (\%): C, 66.04; H, 4.31; N, 9.62.

\section{2) 5-(4-Chlorostyryl)-2-phenylimidazo[1,2-c] quinazoline; 15}

Recrystallized from DMF/methanol, yellowish orange crystals, yield\%: 63\%, m.p.: $193^{\circ} \mathrm{C}-195^{\circ} \mathrm{C}$, IR (KBr, $\mathrm{cm}^{-1}$ ): 3048 (C-H aromatic); 2924 (C-H aliphatic), $1604(\mathrm{C}=\mathrm{N}) ; 1587$ (C=C). ${ }^{1}$ H-NMR (DMSO-d ${ }_{6}, \delta$ ppm): 6.98 (s, $\left.1 \mathrm{H}, \mathrm{CH}=\mathrm{CH}-4-\mathrm{Cl}-\mathrm{C}_{6} \mathrm{H}_{4}\right), 7.04$ (s, $\left.1 \mathrm{H}, \underline{\mathrm{CH}}=\mathrm{CH}-4-\mathrm{Cl}_{-} \mathrm{C}_{6} \mathrm{H}_{4}\right) ; 7.48\left(\mathrm{~d}, 1 \mathrm{H}, \mathrm{J}=8.1 \mathrm{~Hz}\right.$, quinazoline- $\left.\mathrm{C}_{5}-\mathrm{H}\right)$; 7.53 (d, 2H, J = $\left.8.3 \mathrm{~Hz}, 4-\mathrm{Cl}_{-} \mathrm{C}_{6} \mathrm{H}_{4}-\mathrm{C}_{2,6}-\mathrm{H}\right) ; 7.66$ - 7.70 (m, 5H, $\left.\mathrm{C}_{6} \mathrm{H}_{5}\right) ; 7.79-7.85$ (m, 3H, quinazoline- $\mathrm{C}_{6,7,8}-\mathrm{H}$ ); 7.96 (s, $1 \mathrm{H}, \mathrm{CH}$-imidazole), 8.01 (d, $\left.2 \mathrm{H}, \mathrm{J}=8.3 \mathrm{~Hz}, 4-\mathrm{Cl}-\mathrm{C}_{6} \mathrm{H}_{4}-\mathrm{C}_{3,5} \mathrm{-H}\right) . \mathbf{M S} \mathrm{m} / \mathrm{z}$ (relative intensity \%): $381\left(\mathrm{M}^{+}\right.$, 1.09); 76 (100). Anal. Form: $\mathrm{C}_{24} \mathrm{H}_{16} \mathrm{ClN}_{3}$ (381.5) Calcd. (\%): C, 75.49; H, 4.19; N, 11.00. Found (\%): C, 75.57; H, 4.28; N, 11.09.

\subsubsection{5-(4-Chlorostyryl)imidazo[1,2-c]quinazolin-2(3H)-One; 16}

A mixture of compound 8 ( $2.8 \mathrm{~g}, 0.1 \mathrm{~mol})$ and chloroacetyl chloride $(1.7 \mathrm{~g}, 1.2 \mathrm{~mL}, 0.15 \mathrm{~mol})$ was refluxed in dry toluene $(30 \mathrm{~mL})$ in presence of anhydrous potassium carbonate $(1.37 \mathrm{~g}, 0.1 \mathrm{~mol})$ for $8 \mathrm{~h}$. The reaction mixture was then filtered while hot and the filtrate was poured onto crushed ice to yield the desired product which was filtered, washed with water, dried and recrystallized from ethanol.

White crystals, yield\%: 41\%, m.p., $>360^{\circ} \mathrm{C}$, IR $\left(\mathrm{KBr}, \mathrm{cm}^{-1}\right)$ : 3096 (C-H aromatic); 2952 (C-H aliphatic); $1680(\mathrm{C}=\mathrm{O}) ; 1617(\mathrm{C}=\mathrm{N}), 1484(\mathrm{C}=\mathrm{C}) .{ }^{1} \mathrm{H}-\mathrm{NMR}\left(\mathrm{DMSO}-\mathrm{d}_{6}, \delta \mathrm{ppm}\right): 3.55\left(\mathrm{~s}, 2 \mathrm{H}\right.$, imidazole- $\mathrm{C}_{5}-\mathrm{CH}_{2}$ tautomer); $7.07\left(\mathrm{~m}, 1 \mathrm{H}, \mathrm{CH}=\underline{\mathrm{CH}}-4-\mathrm{Cl}_{-} \mathrm{C}_{6} \mathrm{H}_{4}\right) ; 7.26-7.27\left(\mathrm{~m}, 1 \mathrm{H}, \underline{\mathrm{CH}}=\mathrm{CH}-4-\mathrm{Cl}_{-} \mathrm{C}_{6} \mathrm{H}_{4}\right) ; 7.50\left(\mathrm{~s}, 1 \mathrm{H}\right.$, imidazole- $\mathrm{C}_{5},=\mathrm{CH}$ tautomer); 7.68 - $7.86\left(\mathrm{~m}, 8 \mathrm{H}\right.$, two $\left.\mathrm{C}_{6} \mathrm{H}_{4}\right) ; 8.51$ (s, $1 \mathrm{H}, \mathrm{OH}$ tautomer, $\mathrm{D}_{2}$ Oexchangeable). MS m/z (relative intensity \%): $323\left(\mathrm{M}^{+\cdot}+2\right.$, 0.53); $321\left(\mathrm{M}^{+}, 1.03\right) ; 53$ (100). Anal. Form: $\mathrm{C}_{18} \mathrm{H}_{12} \mathrm{ClN}_{3} \mathrm{O}$ (321.5). Calcd. (\%): $\mathrm{C}$, 67.18; H, 3.73; N, 13.06. Found (\%): C, 67.24; H, 3.81; N, 13.19 .

\subsubsection{6-(4-Chlorostyryl)-3,4-diphenyl-4H-[1,2,4] triazino[4,3-c]quinazoline; 17}

An equimolar mixture of compound $9(3 \mathrm{~g}, 0.1 \mathrm{~mol})$ and benzoin $(2.1 \mathrm{~g}, 1.6 \mathrm{~mL}, 0.1 \mathrm{~mol})$ in ethanol $(30 \mathrm{~mL})$ containing few drops of glacial acetic acid (2 - 3 drops) was refluxed for $8 \mathrm{~h}$. The reaction mixture was cooled and the obtained solid was filtered, dried and recrystallized from acetone.

Yellowish white crystals, yield\%: $43 \%$, m.p.: $100^{\circ} \mathrm{C}-102^{\circ} \mathrm{C}$, IR $\left(\mathrm{KBr}, \mathrm{cm}^{-1}\right): 3044$ (C-H aromatic); 1600 $(\mathrm{C}=\mathrm{N}) ; 1569(\mathrm{C}=\mathrm{C}) .{ }^{1} \mathbf{H}-\mathrm{NMR}\left(\mathrm{DMSO}_{-}, \mathrm{d}_{6}, \delta \mathrm{ppm}\right)$ : $6.02\left(\mathrm{~s}, 1 \mathrm{H}\right.$, triazine- $\left.\mathrm{C}_{5}-\mathrm{H}\right) ; 7.22\left(\mathrm{~s}, 1 \mathrm{H}, \mathrm{CH}=\underline{\mathrm{CH}}-4-\mathrm{Cl}-\mathrm{C}_{6} \mathrm{H}_{4}\right)$; $7.23\left(\mathrm{~s}, 1 \mathrm{H}, \underline{\mathrm{CH}}=\mathrm{CH}-4-\mathrm{Cl}_{-} \mathrm{C}_{6} \mathrm{H}_{4}\right)$; 7.24-7.29 (m, 5H, triazine $\left.-\mathrm{C}_{5}-\mathrm{C}_{6} \mathrm{H}_{5}\right) ; 7.31$ - $7.37\left(\mathrm{~m}, 5 \mathrm{H}\right.$, triazine $\left.-\mathrm{C}_{6}-\mathrm{C}_{6} \mathrm{H}_{5}\right)$; $7.41\left(\mathrm{~d}, 2 \mathrm{H}, \mathrm{J}=8.3 \mathrm{~Hz}, 4-\mathrm{Cl}_{-} \mathrm{C}_{6} \mathrm{H}_{4}-\mathrm{C}_{2,6}-\mathrm{H}\right) ; 7.44-7.48\left(\mathrm{~m}, 2 \mathrm{H}\right.$, quinazoline- $\left.\mathrm{C}_{6,7}-\mathrm{H}\right) ; 7.53$ (d, $1 \mathrm{H}, \mathrm{J}=8.1 \mathrm{~Hz}$, quinazoline- $\left.\mathrm{C}_{5}-\mathrm{H}\right) ; 7.57$ - 7.60 (m, $1 \mathrm{H}$, quinazoline- $\left.\mathrm{C}_{8}-\mathrm{H}\right) ; 7.99\left(\mathrm{~d}, 2 \mathrm{H}, \mathrm{J}=8.3 \mathrm{~Hz}, 4-\mathrm{Cl}_{-} \mathrm{C}_{6} \mathrm{H}_{4}-\mathrm{C}_{3,5}-\mathrm{H}\right) . \mathrm{MS} \mathrm{m} / \mathrm{z}$ (relative intensity \%): $472\left(\mathrm{M}^{+}, 1.04\right) ; 76$ (100). Anal. Form: $\mathrm{C}_{30} \mathrm{H}_{21} \mathrm{ClN}_{4}$ (472.5) Calcd. (\%): C, 76.19; H, 4.44; N, 11.85. Found (\%): C, 76.22; H, 4.52; N, 11.97.

\subsubsection{6-(4-Chlorostyryl)-2H-[1,2,4] triazino[4,3-c]quinazolin-3(4H)-one; 18}

Compound 9 ( $3 \mathrm{~g}, 0.1 \mathrm{~mol})$ and chloroacetyl chloride $(1.7 \mathrm{~g}, 1.2 \mathrm{~mL}, 0.15 \mathrm{~mol})$ were stirred in dry DMF (30 mL) for $2 \mathrm{~h}$ at room temperature, then refluxed for another $5 \mathrm{~h}$. The reaction mixture was allowed to cool then poured onto crushed ice. The solid separated was filtered, washed with water, dried and recrystallized from ethanol.

Black crystals, yield \%: 52\%, m.p.: $150^{\circ} \mathrm{C}-152^{\circ} \mathrm{C}$, IR $\left(\mathrm{KBr}, \mathrm{cm}^{-1}\right)$ : $3416(\mathrm{NH}) ; 3039$ (C-H aromatic); 2922 (C-H aliphatic); $1674(\mathrm{C}=\mathrm{O}) ; 1618(\mathrm{C}=\mathrm{N}) ; 1461$ (C=C). ${ }^{1} \mathbf{H}-\mathrm{NMR}$ (DMSO-d ${ }_{6}, \delta$ ppm): 4.25 (s, 2H, $\left.\mathrm{CH}_{2}\right) ; 7.30$ (s, $\left.1 \mathrm{H}, \mathrm{CH}=\underline{\mathrm{CH}}-4-\mathrm{Cl}-\mathrm{C}_{6} \mathrm{H}_{4}\right) ; 7.31\left(\mathrm{~s}, 1 \mathrm{H}, \underline{\mathrm{CH}}=\mathrm{CH}-4-\mathrm{Cl}-\mathrm{C}_{6} \mathrm{H}_{4}\right) ; 7.32-7.46\left(\mathrm{~m}, 2 \mathrm{H}\right.$, quinazoline- $\left.\mathrm{C}_{6,7}-\mathrm{H}\right) ; 7.51(\mathrm{~d}$, $\left.2 \mathrm{H}, \mathrm{J}=8.1 \mathrm{~Hz}, 4-\mathrm{Cl}_{-} \mathrm{C}_{6} \mathrm{H}_{4}-\mathrm{C}_{2,6}-\mathrm{H}\right) ; 7.61\left(\mathrm{~d}, 1 \mathrm{H}, \mathrm{J}=8.1 \mathrm{~Hz}\right.$, quinazoline- $\left.\mathrm{C}_{5}-\mathrm{H}\right) ; 7.77\left(\mathrm{~d}, 2 \mathrm{H}, \mathrm{J}=8.1 \mathrm{~Hz}, 4-\mathrm{Cl}_{-} \mathrm{C}_{6}{ }^{-}\right.$ $\left.\mathrm{H}_{4}-\mathrm{C}_{3,5}-\mathrm{H}\right) ; 8.08\left(\mathrm{~d}, 1 \mathrm{H}, \mathrm{J}=8.1 \mathrm{~Hz}\right.$, quinazoline- $\left.\mathrm{C}_{8}-\mathrm{H}\right) ; 12.20$ (s, $1 \mathrm{H}, \mathrm{NH}, \mathrm{D}_{2} \mathrm{O}$ exchangeable). $\mathrm{MS} \mathrm{m} / \mathrm{z}$ (relative intensity \%): 336 ( $\mathrm{M}^{+}, 1.13$ ); 64(100). Anal. Form: $\mathrm{C}_{18} \mathrm{H}_{13} \mathrm{ClN}_{4} \mathrm{O}$ (336.5). Calcd. (\%): C, 64.19; H, 3.86; N, 16.64. Found (\%): C, 64.22; H, 3.53; N, 16.74.

\subsubsection{2-[2-(4-Chlorostyryl)quinazolin-4-yl]-N-phenylhydrazine Carbothioamide; 19}

A mixture of compound 9 (3 g, $0.01 \mathrm{~mol})$ and phenyl isothiocyanate $(1.4 \mathrm{~g}, 1.2 \mathrm{~mL}, 0.01 \mathrm{~mol})$ in methanol (25 
$\mathrm{mL}$ ) was refluxed for $12 \mathrm{~h}$. The solvent was evaporated. The obtained compound was filtered off, washed with methanol and recrystallized from ethanol.

Yellow crystals, yield\%: $75 \%$, m.p:, $108^{\circ} \mathrm{C}-110^{\circ} \mathrm{C}$, IR $\left(\mathrm{KBr}, \mathrm{cm}^{-1}\right)$ : 3210, 3183 (NH); 3014 (C-H aromatic); 1534, 1364, 1130, 905 (N-C=S); 1450 (C=C). ${ }^{1} \mathbf{H}-\mathrm{NMR}$ (DMSO-d $\mathrm{d}_{6}, \delta$ ppm): 3.98 (s, 2H, NH-CS-NH, $\mathrm{D}_{2} \mathrm{O}$ exchangeable); $7.13\left(\mathrm{~d}, 1 \mathrm{H}, \mathrm{J}=7.5 \mathrm{~Hz}, \mathrm{CH}=\underline{\mathrm{CH}}-4-\mathrm{Cl}_{-} \mathrm{C}_{6} \mathrm{H}_{4}\right) ; 7.16\left(\mathrm{~d}, 1 \mathrm{H}, \mathrm{J}=7.5 \mathrm{~Hz}, \underline{\mathrm{CH}}=\mathrm{CH}-4-\mathrm{Cl}-\mathrm{C}_{6} \mathrm{H}_{4}\right) ; 7.31$ $7.46(\mathrm{~m}, 13 \mathrm{H}$, aromatic- $-\mathrm{CH}) ; 11.08\left(\mathrm{~s}, 1 \mathrm{H}, \mathrm{NH}\right.$, quinazoline- $\mathrm{C}_{4}-\mathrm{NH}, \mathrm{D}_{2} \mathrm{O}$ exchangeable). $\mathrm{MS} \mathrm{m} / \mathrm{z}$ (relative intensity \%): 431 ( $\left.\mathrm{M}^{+}, 1.11\right) ; 54$ (100). Anal. Form: $\mathrm{C}_{23} \mathrm{H}_{18} \mathrm{ClN}_{5} \mathrm{~S}$ (431.5) Calcd. (\%): C, 63.96; H, 4.17; N, 16.22. Found (\%): C, 64.04; H, 4.24; N, 16.32.

\subsubsection{6-(4-Chlorostyryl)-4-phenyl-2H-[1,2,4,5] tetrazino[1,6-c]quinazolin-3(4H)-thione; 20}

To a solution of compound $19(2.2 \mathrm{~g}, 0.01 \mathrm{~mol})$ in carbon tetrachloride $(30 \mathrm{~mL})$, bromine $(2.4 \mathrm{~g}, 0.8 \mathrm{~mL}, 0.02$ mol) was added drop wise while stirring. After complete addition, the reaction mixture was stirred at room temperature for $12 \mathrm{~h}$. The obtained crystals were separated and washed with carbon tetrachloride.

Yellow needle crystals, yield\%: 55\%, m.p.: $153^{\circ} \mathrm{C}-155^{\circ} \mathrm{C}$, IR $\left(\mathrm{KBr}, \mathrm{cm}^{-1}\right): 3310(\mathrm{NH}) ; 3090,3000(\mathrm{C}-\mathrm{H}$ aromatic); 2924 (C-H aliphatic); $1573(\mathrm{C}=\mathrm{N})$; 1554, 1372, 1115, 1041 (N-C=S); 1508 (C=C). ${ }^{1} \mathbf{H}-\mathrm{NMR}$ (DMSO-d $\left.{ }_{6}, \delta \mathrm{ppm}\right): 4.00\left(\mathrm{~s}, 1 \mathrm{H}, \mathrm{NH}, \mathrm{D}_{2} \mathrm{O}\right.$ exchangeable); 7.12 (s, $\left.1 \mathrm{H}, \mathrm{CH}=\mathrm{CH}-4-\mathrm{Cl}_{-} \mathrm{C}_{6} \mathrm{H}_{4}\right) ; 7.15(\mathrm{~s}, 1 \mathrm{H}$, $\left.\underline{\mathrm{CH}}=\mathrm{CH}-4-\mathrm{Cl}-\mathrm{C}_{6} \mathrm{H}_{4}\right) ; 7.53-7.77(\mathrm{~m}, 13 \mathrm{H}$, aromatic- $\mathrm{CH})$. MS m/z (relative intensity\%): $429\left(\mathrm{M}^{+}, 2.02\right) ; 54$ (100). Anal. Form: $\mathrm{C}_{23} \mathrm{H}_{16} \mathrm{ClN}_{5} \mathrm{~S}$ (429.5) Calcd. (\%): C, 64.26; H, 3.72; N, 16.29. Found (\%): C, 64.28; H, 3.70; N, 16.37.

\subsubsection{4-[2-(4-Chlorobenzylidene)hydrazinyl]-2-(4-chlorostyryl)quinazoline; 21}

Equimolar amounts of compound 9 (3 g, $0.01 \mathrm{~mol})$ and 4-chlorobenzaldehyde (1.4 g, $0.01 \mathrm{~mol})$ were refluxed for $8 \mathrm{~h}$ in absolute ethanol $(30 \mathrm{~mL})$ and in presence of few drops of piperidine as catalyst (2 - 3 drops). The reaction mixture was concentrated and the obtained solid residue was collected and recrystallized from ethanol.

Transparent fine crystals, yield\%: 92\%, m.p.: $233^{\circ} \mathrm{C}-235^{\circ} \mathrm{C}$, IR $\left(\mathrm{KBr}, \mathrm{cm}^{-1}\right): 3422(\mathrm{NH}) ; 3010$ (C-H aromatic); 2952 (C-H aliphatic); 1593 (C=N); 1457 (C=C). MS m/z (relative intensity \%): 419 (M+2, 2.01); 85 (100). Anal. Form: $\mathrm{C}_{23} \mathrm{H}_{16} \mathrm{Cl}_{2} \mathrm{~N}_{4}(419)$ Calcd. (\%): C, 65.87; H, 3.81; N, 13.36. Found (\%): C, 65.92; H, 3.84; N, 13.42.

\subsubsection{2-(4-Chlorophenyl)-3-[2-(4-chlorostyryl)quinazolin-4-yl amino]thiazolidin-4-one; 22}

To a solution of compound 21 (2.1 g, $0.01 \mathrm{~mol})$ and anhydrous $\mathrm{ZnCl}_{2}(2.7 \mathrm{~g}, 0.02 \mathrm{~mol})$ in dry benzene $(50 \mathrm{~mL})$, thioglycolic acid ( $1.8 \mathrm{~g}, 1.4 \mathrm{~mL}, 0.02 \mathrm{~mol})$ was added drop wise while stirring at ambient temperature. The reaction mixture was kept for 3 days at room temperature and then refluxed for $14 \mathrm{~h}$. The reaction mixture was filtered. The filtrate was concentrated and poured onto crushed ice. The obtained solid was collected and washed with several solvents.

Black crystals, yield\%: 82\%, m.p., $>360^{\circ} \mathrm{C}$, IR $\left(\mathrm{KBr}, \mathrm{cm}^{-1}\right)$ : 3428 (NH); 3000 (C-H aromatic); 2927 (C-H aliphatic); 1690 (C=O); $1610(\mathrm{C}=\mathrm{N}), 1410(\mathrm{C}=\mathrm{C}) ; 1290,1163$ (C-S-C). MS m/z (relative intensity \%): $493\left(\mathrm{M}^{+}\right.$, 2.02); 50 (100). Anal. Form: $\mathrm{C}_{25} \mathrm{H}_{18} \mathrm{Cl}_{2} \mathrm{~N}_{4} \mathrm{OS}$ (493) Calcd. (\%): C, 60.85; H, 3.65; N, 11.35; S, 6.49. Found (\%): C, 60.94; H, 3.72; N, 11.51; S, 6.47.

\subsubsection{3-Chloro-4-(4-chlorophenyl)-1-[2-(4-chlorostyryl)quinazolin-4-yl amino]azetidin-2-one; 23}

To a solution of compound $21(2.1 \mathrm{~g}, 0.01 \mathrm{~mol})$ in dry benzene $(50 \mathrm{~mL})$ containing triethyl amine $(1 \mathrm{~mL})$ as a base, chloroacetyl chloride ( $1.7 \mathrm{~g}, 1.2 \mathrm{~mL}, 0.015 \mathrm{~mol}$ ) was added drop wise at room temperature. The reaction mixture was stirred for 40 minutes then refluxed for $32 \mathrm{~h}$. The reaction mixture was filtered while hot to remove the triethyl amine hydrogen chloride salt and the filtrate was poured onto crushed ice with continuous stirring. The solid obtained was maintained in the refrigerator for 7 days.

Solid with low melting point, yield \%: 84\%, IR (KBr, cm $\left.{ }^{-1}\right)$ : $3402(\mathrm{OH})$; 3290, 3240 (NH); 3004 (C-H aromatic), 2804 (C-H aliphatic); $1720(\mathrm{C}=\mathrm{O}) ; 1635(\mathrm{C}=\mathrm{N}) ; 1465$ (C=C). ${ }^{1} \mathrm{H}-\mathrm{NMR}$ (DMSO-d 6 , $\delta$ ppm): 4.06 (d, $1 \mathrm{H}$, $\left.\mathrm{J}=9 \mathrm{~Hz}, \underline{\mathrm{CH}}-\mathrm{C}_{6} \mathrm{H}_{4}-\mathrm{Cl}\right) ; 4.30(\mathrm{~d}, 1 \mathrm{H}, \mathrm{J}=9 \mathrm{~Hz}, \underline{\mathrm{CH}}-\mathrm{Cl}) ; 7.90$ (s, $\left.1 \mathrm{H}, \mathrm{CH}=\underline{\mathrm{CH}}-4-\mathrm{Cl}_{-} \mathrm{C}_{6} \mathrm{H}_{4}\right) ; 8.06(\mathrm{~s}, 1 \mathrm{H}$, $\left.\underline{\mathrm{CH}}=\mathrm{CH}-4-\mathrm{Cl}-\mathrm{C}_{6} \mathrm{H}_{4}\right) ; 8.68$ - $9.42\left(\mathrm{~m}, 12 \mathrm{H}\right.$, two 4-Cl- $\underline{\mathrm{C}}_{6} \underline{\mathrm{H}}_{4}$ \& quinazoline- $\left.\mathrm{C}_{5,6,7,8}-\mathrm{H}\right) ; 10.68$ (s, $1 \mathrm{H}, \mathrm{NH}, \mathrm{D}_{2} \mathrm{O}$ exchangeable). MS m/z (relative intensity \%): 495 ( $\mathrm{M}^{+}, 0.82$ ); 62 (100). Anal. Form: $\mathrm{C}_{25} \mathrm{H}_{17} \mathrm{Cl}_{3} \mathrm{~N}_{4} \mathrm{O}$ (495.5) Calcd. (\%): C, 60.54; H, 3.43; N, 11.30. Found (\%): C, 60.62; H, 3.44; N, 11.39. 
3.1.21. 3-(4-Chlorophenyl)-5-(4-chlorostyryl)-[1,2,4]triazolo[4,3-c]quinazoline; 24

Compound 21 ( $2.1 \mathrm{~g}, 0.01 \mathrm{~mol})$ was refluxed in glacial acetic acid $(15 \mathrm{~mL})$ for $14 \mathrm{~h}$ in presence of anhydrous sodium acetate (1.5 g, $0.02 \mathrm{~mol}$.). The reaction mixture was then filtered while hot, the filtrate was poured onto crushed ice. The obtained solid was filtered, washed with water and recrystallized from ethanol.

Black crystals, yield\%: 52\%, m.p.: $90^{\circ} \mathrm{C}-92^{\circ} \mathrm{C}$, IR $\left(\mathrm{KBr}, \mathrm{cm}^{-1}\right)$ : 3010 (C-H aromatic); 2900 (C-H aliphatic); 1641 (C=N); 1569 (C=C). MS m/z (relative intensity \%): $417\left(\mathrm{M}^{+}\right.$, 28.57); 81 (100). Anal. Form: $\mathrm{C}_{23} \mathrm{H}_{14} \mathrm{Cl}_{2} \mathrm{~N}_{4}$ (417) Calcd. (\%): C, 66.18; H, 3.35; N, 13.42. Found (\%): C, 66.19; H, 3.42; N, 13.58.

\subsubsection{General Procedure for Synthesis of Compounds 25, 26 and 27}

An equimolar mixture of compound 7 ( $1.6 \mathrm{~g}, 0.01 \mathrm{~mol})$ and the appropriate amine namely; 2-aminoethanol (0.3 g, $0.3 \mathrm{~mL}, 0.01 \mathrm{~mol})$, dimethyl amine $(0.5 \mathrm{~g}, 0.6 \mathrm{~mL}, 0.01 \mathrm{~mol})$ or pyrrole $(0.3 \mathrm{~g}, 0.3 \mathrm{~mL}, 0.01 \mathrm{~mol})$ was fused for $18 \mathrm{~h}$. The reaction mixture was allowed to cool then triturated with ethanol. The obtained solid was filtered off to yield compounds 25,26 and 27; respectively.

\section{1) 2[2-(4-Chlorostyryl)quinazolin-4-ylamino]ethanol; 25}

Recrystallized from ethanol, yellowish white crystals, yield\%: 42\%, m.p.: $>360^{\circ} \mathrm{C}$, IR $\left(\mathrm{KBr}, \mathrm{cm}^{-1}\right)$ : $3435(\mathrm{OH}$ broad band); 3184, 3126 (NH); 3046 (C-H aromatic); 2923, 2856 (C-H aliphatic); 1604 (C=N); 1571 (C=C). ${ }^{1} \mathrm{H}-\mathrm{NMR}$ (DMSO-d $\left.\mathrm{d}_{6}, \delta \mathrm{ppm}\right): 3.66-3.71\left(\mathrm{~m}, 4 \mathrm{H}, \mathrm{HN}-\mathrm{CH}_{2}-\mathrm{CH}_{2}-\mathrm{OH}\right) ; 4.40$ (s, $1 \mathrm{H}, \mathrm{OH}, \mathrm{D}_{2} \mathrm{O}$ exchangeable); 7.19 (s, $\left.1 \mathrm{H}, \mathrm{CH}=\underline{\mathrm{CH}}-4-\mathrm{Cl}-\mathrm{C}_{6} \mathrm{H}_{4}\right) ; 7.22\left(\mathrm{~s}, 1 \mathrm{H}, \underline{\mathrm{CH}}=\mathrm{CH}-4-\mathrm{Cl}_{-} \mathrm{C}_{6} \mathrm{H}_{4}\right) ; 7.38\left(\mathrm{~d}, 1 \mathrm{H}, \mathrm{J}=6.5 \mathrm{~Hz}\right.$, quinazoline- $\left.\mathrm{C}_{5}-\mathrm{H}\right)$; 7.40 - 7.48 (m, 2H, quinazoline- $\left.\mathrm{C}_{6,7}-\mathrm{H}\right) ; 7.53$ (d, 2H, J = 7.5 Hz, 4-Cl- $\left.\mathrm{C}_{6} \mathrm{H}_{4}-\mathrm{C}_{2,6}-\mathrm{H}\right) ; 7.67$ (d, $1 \mathrm{H}, \mathrm{J}=6.5 \mathrm{~Hz}$, quinazoline- $\mathrm{C}_{8}-\mathrm{H}$ ); 8.11 (d, $\left.2 \mathrm{H}, \mathrm{J}=7.5 \mathrm{~Hz}, 4-\mathrm{Cl}_{-} \mathrm{C}_{6} \mathrm{H}_{4}-\mathrm{C}_{3,5}-\mathrm{H}\right) ; 12.35$ (s, $1 \mathrm{H}, \mathrm{NH}, \mathrm{D}_{2} \mathrm{O}$ exchangeable). $\mathrm{MS} \mathrm{m} / \mathrm{z}$ (relative intensity \%): $327\left(\mathrm{M}^{+\bullet}+2\right.$, 1.34), 325 ( $\mathrm{M}^{+}$, 2.35); 78 (100). Anal. Form: $\mathrm{C}_{18} \mathrm{H}_{16} \mathrm{ClN}_{3} \mathrm{O}$ (325.5) Calcd. (\%): C, 66.35; H, 4.91; N, 12.90. Found (\%): C, 66.41; H, 5.03; N, 13.04.

\section{2) 2-(4-Chlorostyryl)- $N, N$-dimethylquinazoline-4-amine; 26}

Recrystalized from ethanol, white crystals, yield\%: 53\%, m.p.: $298^{\circ} \mathrm{C}-300^{\circ} \mathrm{C}, \mathbf{I R}\left(\mathrm{KBr}, \mathrm{cm}^{-1}\right)$ : $3055(\mathrm{C}-\mathrm{H}$

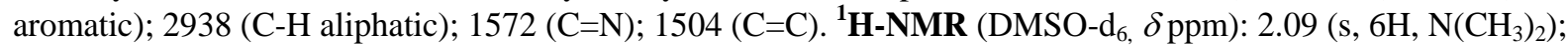
6.99 (s, $\left.1 \mathrm{H}, \mathrm{CH}=\underline{\mathrm{CH}}-4-\mathrm{Cl}-\mathrm{C}_{6} \mathrm{H}_{4}\right) ; 7.04\left(\mathrm{~s}, 1 \mathrm{H}, \underline{\mathrm{CH}}=\mathrm{CH}-4-\mathrm{Cl}_{-} \mathrm{C}_{6} \mathrm{H}_{4}\right) ; 7.48\left(\mathrm{~d}, 2 \mathrm{H}, \mathrm{J}=6.9 \mathrm{~Hz}\right.$, quinazoline- $\left.\mathrm{C}_{6,7}-\mathrm{H}\right)$; $7.53\left(\mathrm{~d}, 2 \mathrm{H}, \mathrm{J}=8.7 \mathrm{~Hz}, 4-\mathrm{Cl}-\mathrm{C}_{6} \mathrm{H}_{4}-\mathrm{C}_{2,6}-\mathrm{H}\right) ; 7.69\left(\mathrm{~d}, 2 \mathrm{H}, \mathrm{J}=8.7 \mathrm{~Hz}, 4-\mathrm{Cl}_{-} \mathrm{C}_{6} \mathrm{H}_{4}-\mathrm{C}_{3,5}-\mathrm{H}\right) ; 7.83(\mathrm{~d}, 1 \mathrm{H}, \mathrm{J}=6.9 \mathrm{~Hz}$, quinazoline $\left.-\mathrm{C}_{5}-\mathrm{H}\right) ; 8.11\left(\mathrm{~d}, 1 \mathrm{H}, \mathrm{J}=7.8 \mathrm{~Hz}\right.$, quinazoline- $\left.\mathrm{C}_{8}-\mathrm{H}\right)$. MS $\mathrm{m} / \mathrm{z}$ (relative intensity \%): $309\left(\mathrm{M}^{+*}, 0.02\right)$; 62 (100). Anal. Form: $\mathrm{C}_{18} \mathrm{H}_{16} \mathrm{ClN}_{3}$ (309.5) Calcd. (\%): C, 69.78; H, 5.16; N, 13.57. Found (\%): C, 69.86; H, 5.24; N, 13.62.

\section{3) 2-(4-Chlorostyryl)-4-(1H-pyrrol-1-yl)quinazoline; 27}

Recrystallized from DMF, black crystals, yield\%: 67\%, m.p.: $>360^{\circ} \mathrm{C}$, IR $\left(\mathrm{KBr}, \mathrm{cm}^{-1}\right): 3124$ (C-H aromatic); $1657(\mathrm{C}=\mathrm{N}) ; 1530(\mathrm{C}=\mathrm{C}) .{ }^{1} \mathrm{H}-\mathrm{NMR}\left(\mathrm{DMSO}-\mathrm{d}_{6}, \delta \mathrm{ppm}\right): 6.55$ (s, 2H, $\left.\underline{\mathrm{CH}}=\underline{\mathrm{CH}}\right) ; 7.69$ (s, 2H, pyrrole- $\left.\mathrm{C}_{3,4}-\mathrm{H}\right) ;$ 7.70 (s, $2 \mathrm{H}$, pyrrole- $\left.\mathrm{C}_{2,5}-\mathrm{H}\right) ; 7.92-8.00\left(\mathrm{~m}, 8 \mathrm{H}, 4-\mathrm{Cl}-\underline{\mathrm{C}}_{6} \underline{\mathrm{H}}_{4}\right.$ \& quinazoline- $\mathrm{C}_{5,6,7,8} \mathrm{H}$ ). MS m/z (relative intensity \%): $331\left(\mathrm{M}^{+*}, 1.22\right) ; 54$ (100). Anal. Form: $\mathrm{C}_{20} \mathrm{H}_{14} \mathrm{ClN}_{3}$ (331.5) Calcd. (\%): C, 72.39; H, 4.22; N, 12.66. Found (\%): C, 72.45; H, 4.23; N, 12.72.

\subsubsection{General Procedure for Synthesis of Compounds 28 and 29}

A mixture of compound 7 (1.6 g, $0.01 \mathrm{~mol})$ and anthranilic acid $(1.4 \mathrm{~g}, 0.02 \mathrm{~mol})$ was refluxed for $12 \mathrm{~h}$ in glacial acetic acid $(30 \mathrm{~mL})$. The reaction mixture was concentrated and filtered while hot to yield compound $\mathbf{2 8}$. The filtrate was poured onto crushed ice and the obtained solid was collected to give compound 29.

\section{1) 8H-6-(4-Chlorostyryl)quinazolino[4,3-b]quinazolin-8-one; 28}

Recrystallized from ethanol, yellow crystals, yield\%: 44\%, m.p.: $>360^{\circ} \mathrm{C}, \mathrm{IR}\left(\mathrm{KBr}, \mathrm{cm}^{-1}\right): 3057(\mathrm{C}-\mathrm{H}$ aromatic), 2922 (C-H aliphatic); $1690(\mathrm{C}=\mathrm{O}) ; 1637(\mathrm{C}=\mathrm{N}) ; 1570(\mathrm{C}=\mathrm{C}) .{ }^{1} \mathbf{H}-\mathrm{NMR}$ (DMSO-d $\mathrm{d}_{6}, \delta$ ppm): 7.30 (s, $\left.1 \mathrm{H}, \mathrm{CH}=\mathrm{CH}-4-\mathrm{Cl}_{-} \mathrm{C}_{6} \mathrm{H}_{4}\right) ; 7.35$ (s, $\left.1 \mathrm{H}, \underline{\mathrm{CH}}=\mathrm{CH}-4-\mathrm{Cl}_{-} \mathrm{C}_{6} \mathrm{H}_{4}\right) ; 7.50\left(\mathrm{~d}, 2 \mathrm{H}, \mathrm{J}=8.5 \mathrm{~Hz}, 4-\mathrm{Cl}_{-} \mathrm{C}_{6} \mathrm{H}_{4}-\mathrm{C}_{2,6}-\mathrm{H}\right) ; 7.82(\mathrm{~d}$, $\left.2 \mathrm{H}, \mathrm{J}=8.5 \mathrm{~Hz}, 4-\mathrm{Cl}_{-} \mathrm{C}_{6} \mathrm{H}_{4}-\mathrm{C}_{3,5}-\mathrm{H}\right) ; 7.87-7.96$ (m, 8H, quinazoline-C-H). MS m/z (relative intensity \%): 386 $\left(\mathrm{M}^{+}+3\right.$, 0.22); 382 ( $\left.\mathrm{M}^{+*}-1,0.22\right)$; 54 (100). Anal. Form: $\mathrm{C}_{23} \mathrm{H}_{14} \mathrm{ClN}_{3} \mathrm{O}$ (383). Calcd. (\%): C, 71.96; H, 3.65; N, 10.95. Found (\%): C, 71.81; H, 3.71; N, 11.03 .

\section{2) 2-[2-(4-Chlorostyryl)quinazolin-4-amino]benzoic acid; 29}

Recrystallized from ethanol, brown crystals, yield\%: 85\%, m.p., $203^{\circ} \mathrm{C}-205^{\circ} \mathrm{C}, \mathbf{I R}\left(\mathrm{KBr}, \mathrm{cm}^{-1}\right): 3179(\mathrm{NH})$; 2920 (broad OH, Hydrogen bonded); $1683(\mathrm{C}=\mathrm{O}) ; 1603(\mathrm{C}=\mathrm{N}) ; 1519(\mathrm{C}=\mathrm{C}) .{ }^{1} \mathrm{H}-\mathrm{NMR}\left(\mathrm{DMSO}_{6} \mathrm{~d}_{6}, \delta \mathrm{ppm}\right): 6.99$ (s, $\left.1 \mathrm{H}, \mathrm{CH}=\mathrm{CH}-4-\mathrm{Cl}_{-} \mathrm{C}_{6} \mathrm{H}_{4}\right) ; 7.04\left(\mathrm{~s}, 1 \mathrm{H}, \underline{\mathrm{CH}}=\mathrm{CH}-4-\mathrm{Cl}_{-} \mathrm{C}_{6} \mathrm{H}_{4}\right) ; 7.24-7.33\left(\mathrm{~m}, 1 \mathrm{H}\right.$, aminophenyl- $\left.\mathrm{C}_{4}-\mathrm{H}\right) ; 7.37(\mathrm{~d}$, $1 \mathrm{H}, \mathrm{J}=7.8 \mathrm{~Hz}$, aminophenyl- $\left.\mathrm{C}_{6}-\mathrm{H}\right) ; 7.47-7.55\left(\mathrm{~m}, 1 \mathrm{H}\right.$, aminophenyl- $\left.\mathrm{C}_{5}-\mathrm{H}\right) ; 7.69(\mathrm{~d}, 2 \mathrm{H}, \mathrm{J}=8.4 \mathrm{~Hz}$, 
4-Cl- $\left.\mathrm{C}_{6} \mathrm{H}_{4}-\mathrm{C}_{2,6}-\mathrm{H}\right) ; 7.78$ (d, $1 \mathrm{H}, \mathrm{J}=8.1 \mathrm{~Hz}$, quinazoline-C $\left.-\mathrm{H}\right) ; 7.83$ (d, 2H, J = 8.4 Hz, 4-Cl- $\left.\mathrm{C}_{6} \mathrm{H}_{4}-\mathrm{C}_{3,5}-\mathrm{H}\right) ; 7.87$ - $8.01\left(\mathrm{~m}, 2 \mathrm{H}\right.$, quinazoline- $\left.\mathrm{C}_{6,7}-\mathrm{H}\right) ; 8.12\left(\mathrm{~d}, 1 \mathrm{H}, \mathrm{J}=8.1 \mathrm{~Hz}\right.$, quinazoline- $\left.\mathrm{C}_{8}-\mathrm{H}\right) ; 8.34(\mathrm{~d}, 1 \mathrm{H}, \mathrm{J}=7.8 \mathrm{~Hz}$, aminophenyl- $\left.\mathrm{C}_{3}-\mathrm{H}\right) ; 8.76$ (s, $1 \mathrm{H}, \mathrm{NH}, \mathrm{D}_{2} \mathrm{O}$ exchangeable); 12.18 (s, $1 \mathrm{H}, \mathrm{OH}, \mathrm{D}_{2} \mathrm{O}$ exchangeable) . MS m/z (relative intensity \%): 401 ( $\left.\mathrm{M}^{+}, 0.50\right) ; 64$ (100). Anal. Form: $\mathrm{C}_{23} \mathrm{H}_{16} \mathrm{ClN}_{3} \mathrm{O}_{2}$ (401) Calcd. (\%): C, 68.79; H, 3.98; N, 10.46. Found (\%): C, 68.80; H, 3.97; N, 10.52.

\subsection{Biology}

\subsubsection{Anticancer Screening}

The synthesized compounds were screened for their in vitro cytotoxic activity against human hepatocellular liver carcinoma (Hep-G2) and human breast cancer cell line (MCF-7). Doxorubicin was used as the reference drug.

\section{Mammalian cell lines}

MCF-7 cells (human breast cancer cell line) were obtained from VACSERA Tissue culture unit. Hep-G2 cells (human cell line of a well differentiated hepatocellular carcinoma isolated from a liver biopsy of a male Caucasian aged 15 years) were obtained from the American type culture collection (ATCC).

\subsubsection{Cell line Propagation}

The cells were propagated in Dulbecco's modified Eagle's medium (DMEM) supplemented with 10\% heat-inactivated fetal bovine serum, 1\% L-glutamine, HEPES buffer and $50 \mu \mathrm{g} / \mathrm{mL}$ gentamycin. All cells were maintained at $37^{\circ} \mathrm{C}$ in a humidified atmosphere with $5 \% \mathrm{CO}_{2}$ and were subcultured two times a week.

\subsubsection{Cytotoxicity Evaluation Using Viability Assay}

For cytotoxicity assay, the cells were seeded in 96-well plate at a cell concentration of $1 \times 10^{4}$ cells per well in 100 $\mu \mathrm{L}$ of growth medium. Fresh medium containing different concentrations of the test sample was added after 24 $\mathrm{h}$ of seeding. Serial two-fold dilutions of the tested chemical compound were added to confluent cell monolayers dispensed into 96-well, flat-bottomed microtiter plates (Falcon, NJ, USA) using a multichannel pipette. The microtiter plates were incubated at $37^{\circ} \mathrm{C}$ in a humidified incubator with $5 \% \mathrm{CO}_{2}$ for a period of $48 \mathrm{~h}$. Three wells were used for each concentration of the test sample. Control cells were incubated without test sample and with or without DMSO. The little percentage of DMSO present in the wells (maximal $0.1 \%$ ) was found not to affect the experiment. After incubation of the cells for $24 \mathrm{~h}$ at $37^{\circ} \mathrm{C}$, various concentrations of sample (50, 25, 12.5, 6.25, $3.125 \& 1.56 \mu \mathrm{g} / \mathrm{L}$ ) were added, and the incubation was continued for $48 \mathrm{~h}$ and viable cells yield was determined by a colorimetric method. After the end of the incubation period, media were aspirated and the crystal violet solution (1\%) was added to each well for at least 30 minutes. The stain was removed and the plates were rinsed using tap water until all excess stain is removed. Glacial acetic acid (30\%) was then added to all wells and mixed thoroughly, and then the absorbance of the plates were measured after gently shaken on Microplate reader (TECAN, Inc.), using a test wavelength of $490 \mathrm{~nm}$. All results were corrected for background absorbance detected in wells without added stain. Treated samples were compared with the cell control in the absence of the tested compounds. All experiments were carried out in triplicate. The cell cytotoxic effect of each tested compound was calculated [49] [50]. The cytotoxicity of the tested compounds was estimated in terms of percent growth inhibition compared to untreated control cells and their $\mathrm{IC}_{50}$ in $\mu \mathrm{M} / \mathrm{L}$ which is the concentration of the compound that inhibits the tumor cell growth by $50 \%$.

\subsection{Computer Aided Docking}

\subsubsection{Materials}

All the molecular studies were carried out on an Intel pentium 1.6 GHz processor, 512 MB memory with windows XP operating system using Molecular Operating Environment (MOE 2005.06; Chemical Computing Group, Montreal, Canada) as the computational software. All the minimizations were performed with MOE until a RMSD gradient of $0.05 \mathrm{Kcal} \mathrm{mol}^{-1} \mathrm{~A}^{0-1}$ with MMFF94X forcefield and the partial charges were automatically calculated.

\subsubsection{General Methodology}

The coordinates of the X-ray crystal structure of 2'-deoxyuridine-5'-monophosphate (DUMP) bound to 
thymidylate synthase enzyme were obtained from Protein Data Bank (PDB ID: 1BID) as well as the coordinates of the X-ray crystal structure of methotrexate (MTX) bound to dihydrofolate reductase (DHFR) enzyme (PDB ID: 4DFR). Enzyme structures were checked for missing atoms, bonds and contacts. Hydrogen atoms were added to the enzyme structure. Water molecules and bound ligands were manually deleted. The ligand molecules were constructed using the builder molecule and were energy minimized. The active site was generated using the MOE-Alpha site finder. Dummy atoms were created from the obtained alpha spheres. Ligands were docked within the thymidylate synthase and dihydrofolate reductase active sites using the MOE-Dock with simulated annealing used as the search protocol and MMFF94X molecular mechanics forcefield for 8000 interactions. The lowest energy conformation was selected and subjected to an energy Minimization using MMFF94X force field.

\section{Conclusion}

Compounds 18, 19, 20, 23 and 24 exhibited very potent anticancer activity against both Hep-G2 and MCF-7 cell lines. However, compounds 10, 15 and 29, showed remarkable anticancer activity against liver Hep-G2 cell line, while compound 22 exhibited potent anticancer activity against MCF-7 cell line. Docking was performed for the five most active anticancer compounds 18, 19, 20, 23 and 24 on the two enzymes; thymidylate synthase and dihydrofolate reductase in a trial to predict their mode of action as anticancer drugs. Also, the compounds show several interactions with both enzymes but they exhibit strong interactions with dihydrofolate reductase enzyme, mainly compounds 18, 19, 23 and 24, giving rise to the conclusion that they might exert their action through inhibition of both enzymes but mainly DHFR enzyme.

\section{Acknowlegements}

The biological anticancer screening was performed in the Regional Center for Mycology and Biotechnology, Al-Azhar University. The Molecular docking study was performed in the pharmaceutical Chemistry Department, Faculty of Pharmacy, Alexandria University.

\section{References}

[1] Witt, A. and Bergman, J. (2003) Recent Developments in the Field of Quinazoline Chemistry. Current Organic Chemistry, 7, 659-677. http://dx.doi.org/10.2174/1385272033486738

[2] Wong, H. and Gansan, A. (2003) Total Synthesis of the Fumiquinazoline Alkaloids: Solution-Phase Studies. Journal of Organic Chemistry, 65, 1022-1030. http://dx.doi.org/10.1021/jo9914364

[3] Micheal, J.P. (2003) Quinoline, Quinazoline and Acridone Alkaloids. Natural Product Reports, 18, 543-559.

[4] Al-Obaid, A.M., Abdel-Hamide, S.G., El-kashef, H.A., Abdel-Aziz, A.A., El-Azab, A.S., Al-khamees, H.A. and El-Subbagh, H.I. (2009) Synthesis, in Vitro Antitumor Activity and Molecular Modeling Study of Certain 2-Thieno-4(3H)-quinazolinone Analogs. European Journal of Medicinal Chemistry, 44, 2379-2391. http://dx.doi.org/10.1016/j.ejmech.2008.09.015

[5] Al-Omary, F.A., Abou-Zeid, L.A., Nagi, M.N., Habib, S., Abdel-Aziz, A.A., El-Azab, A.S., Abdel-Hamide, S.G., Al-Omar, M.A., Al-Obaid, A.M. and El-Subbag, H.I. (2010) Non-Classical Antifoliates Part 2: Synthesis, Biological Evaluation and Molecular Modeling Study of Some New 2,6-Substituted Quinazolin-4-Ones. Bioorganic \& Medicinal Chemistry, 18, 2849-2863. http://dx.doi.org/10.1016/j.bmc.2010.03.019

[6] El-Azab, A.S., Al-Omar, M.A., Abdel-Aziz, A.A., Abdel-Aziz, N.I., El-Sayed, M.A., Aleisa, A.M., Sayed-Ahmad, M.M. and Abdel-Hamide, S.G. (2010) Design, Synthesis and Biological Evaluation of Novel Quinazoline Derivatives as Potential Antitumor Agents: Molecular Docking Study. European Journal of Medicinal Chemistry, 45, 4188-4198. http://dx.doi.org/10.1016/j.ejmech.2010.06.013

[7] Berest, G.G., Voskoboynik, O.Y., Kovalenko, S.I., Antypenko, O.M., Nosulenko, I.S., Katsev, A.M. and Shandrovskaya, O.S. (2011) Synthesis and Biological Activity of Novel N-Cycloalkyl-(cycloalkylaryl)-2-[(3-R-2-oxo-2H[1,2,4]triazino[2,3-c]quinazoline-6-yl)thio]acetamides. European Journal of Medicinal Chemistry, 46, 6066-6074. http://dx.doi.org/10.1016/j.ejmech.2011.10.022

[8] Yadav, M.R., Grande, F., Chouhan, B.S., Naik, P.P., Giridhar, R., Garofalo, A. and Neamati, N. (2012) Cytotoxic Potential of Novel 6,7-Dimethoxyquinazolines. European Journal of Medicinal Chemistry, 24, 231-243.

[9] Li, H., Li, D., Lu, X., Xu, Y. and Zhu, H. (2012) Design and Synthesis of 4,6-Substituted-(diphenylamino)quinazolines as Potent EGFR Inhibitors with Antitumor Activity. Bioorganic \& Medicinal Chemistry, 20, 317-323. 
http://dx.doi.org/10.1016/j.bmc.2011.10.085

[10] Mulakayala, N., Kandagatle, B., Ismail, Rapolu, R.K., Rao, P., Mulakayala, C., Kumar, C.S., Igbal, J. and Oruganti, S. (2012) InCl $_{3-}$ Catalysed Synthesis of 2-Arylquinazolin-4(3H)-ones and 5-Arylpyrazolo[4,3-d]pyrimidin-7(6H)-ones and Their Evaluation as Potential Anticancer Agents. Bioorganic \& Medicinal Chemistry, 22, 5063-5066. http://dx.doi.org/10.1016/j.bmcl.2012.06.003

[11] Zeng, Z., He, Q., Liang, Y., Feng, X., Chen, F., Clercq, E.D., Balzarini, J. and Couque, C.P. (2010) Hybrid Diarylbenzopyrimidine Non-Nucleoside Reverse Transcriptase Inhibitors as Promising New Leads for Improved Anti-HIV-1 Chemotherapy. Bioorganic \& Medicinal Chemistry, 18, 5039-5047. http://dx.doi.org/10.1016/j.bmc.2010.05.081

[12] Mohamed, Y.A., Amr, A., Mohamed, S.F., Abdalla, M.M., Al-Omar, M.A. and Shafik, S.H. (2012) Cytotoxicity and AntiHIV Evaluation of Some New Synthesized Quinazoline and Thiooxopyrimidine Derivatives Using 4-(thiophen-2-yl)-3,4,5,6Tetrahydrobenzo[h]quinazolin-2(1H)-thione as Synthone. Journal of Chemical Sciences, 124, 693-702. http://dx.doi.org/10.1007/s12039-012-0242-4

[13] Vijayakumar, K., Ahamed, A.G. and Thiruneelakandan, G. (2013) Synthesis, Antimicrobial and Anti-HIV1 Activity of Quinazoline-4(3H)-one Derivatives. Journal of Applied Chemistry, 5, 387191.

[14] Sharma, P., Kumar, A., Kumar, P., Singh, J. and Kaushik, M.P. (2011) QSAR Modeling of Synthesized 3-(1,3-benzothiazol2-yl)2-phenyl Quinazolin-4(3H)-ones as Potent Antibacterial Agents. Medicinal Chemistry Research, 21, 1136-1148.

[15] Anand, R.V., Narasimhan, B., Chandran, R.V.P. and Jayaveera, K.N. (2011) 7-Chloro-3-(substituted benzylidene/phenylethylidene amino)-2-phenyl Quinazolin-4(3H)-ones: Synthesis, Antimicrobial and Antitubercular Evaluation. Medicinal Chemistry Research, 21, 2831-2836.

[16] Ryu, C., Kim, Y.H., Im, A.A., Kim, J.Y., Yoon, J.H. and Kim, A. (2012) Synthesis and Antifungal Activity of 6,7bis(arylthio)-quinazoline-5,8-diones and Furo[2,3-f]quinazolin-5-ols. Bioorganic \& Medicinal Chemistry Letters, 22, 500-503. http://dx.doi.org/10.1016/j.bmcl.2011.10.099

[17] Yadav, M.R., Shirude, S.T., Parmar, A., Balaraman, R. and Giridhar, R. (2006) Synthesis and Anti-Inflammatory Activity of 2,3-Diaryl-4(3H)-quinazolines. Chemistry of Heterocyclic Compounds, 42, 1038.

[18] Chandria, P.M., Yakaiah, T., Rao, A.R.R., Narsaiah, B., Reddy, N.C., Sridhar, V. and Rao, J.V. (2008) Synthesis of Novel 4,6-Disubstituted Quinazoline Derivatives, Their Anti-Inflammatory and Anticancer Activity against U937 Leukemia Cell Lines. European Journal of Medicinal Chemistry, 43, 846-852. http://dx.doi.org/10.1016/j.ejmech.2007.06.010

[19] Alafeefy, A.M., Kadi, A.A., El-Azab, A.S., Abdel-Hamide, S.G. and Daba, M.H. (2008) Synthesis, Analgesic and AntiInflammatory Evaluation of Some New 3H-Quinazolin-4-One Derivatives. Archiv der Pharmazie (wein heim), 341, 377-385.

[20] Manivannan, E. and Chaturvedi, S.C. (2011) Analogue-Based Design, Synthesis and Molecular Docking Analysis of 2,3-Diarylquinazolinones as Non-Ulcerogenic Anti-Inflammatory Agents. Bioorganic \& Medicinal Chemistry, 19, 45204588. http://dx.doi.org/10.1016/j.bmc.2011.06.019

[21] Letourneau, J.J., Riviello, C.M., Li, H., Cole, A.G., Ho, K., Zonetakos, H.A., Desai, H., Zhao, J., Auld, D.S., Napier, S.E., Thomson, F.J., Goan, K.A., Morphy, J.R., Ohlmeyer, M.H.J. and Webb, M.L. (2010) Idendification and Optimization of Novel 2-(4-oxo-2-aryl-quinazolin-3(4H)-yl)acetamide Vasopressin V3 (V1b) Receptor Antagonists. Bioorganic \& Medicinal Chemistry Letters, 20, 5394-5397. http://dx.doi.org/10.1016/j.bmcl.2010.07.118

[22] Gupta, A., Kashaw, S.K., Jain, N., Jajak, H., Soni, A. and Stable, J.P. (2011) Design and Synthesis of Some Novel 3[5-(4-Substituted)phenyl-1,3,4-oxadiazole-2-yl]-2-phenylquinazolin-4(3H)-ones as Possible Anticonvulsant Agent. Medicinal Chemistry Research, 20, 1638-1942. http://dx.doi.org/10.1007/s00044-010-9475-2

[23] Kumar, S., Kaur, H. and Kumar, A. (2012) Synthesis of New Azetidinonyl/Thiazolidinonyl Quinazolinone Derivatives as Antiparkinsonian Agents. Arabian Journal of Chemistry, 5, 475-484. http://dx.doi.org/10.1016/j.arabjc.2010.09.014

[24] Laddha, S.S., Wadodkav, S.G. and Meghal, S.K. (2009) cAMP-Dependend Phosphodiesterase Inhibition and SAR Studies on Novel 6,8-Disubstituted-2-phenyl-3-(substituted benzothiazole-2-yl)-4(3H)-quinazolinone. Medicinal Chemistry Research, 18, 268-276. http://dx.doi.org/10.1007/s00044-008-9125-0

[25] Abou Seri, S.M., Abouzid, K. and Abou-El Ella, D.A. (2011) Molecular Modeling Study and Synthesis of QuinazolinoneArylpiperazine Derivatives as $\alpha_{1}$-Adrenoreceptor Antagonists. European Journal of Medicinal Chemistry, 46, 647-658. http://dx.doi.org/10.1016/j.ejmech.2010.11.045

[26] Abouzid, K. and Shouman, S. (2008) Design, Synthesis and in Vitro Antitumor Activity of 4-Aminoquinoline and 4-Aminoquinazoline Derivatives Targeting EGRF Tyrosine Kinase. Bioorganic \& Medicinal Chemistry, 16, 7543-7551. http://dx.doi.org/10.1016/j.bmc.2008.07.038

[27] Morin, M.J. (2000) From Oncogene to Drug: Development of Small Molecule Tyrosine Kinase Inhibitors as Antitumor and Anti-Angiogenic Agents. Oncogene, 19, 6574-6583. http://dx.doi.org/10.1038/sj.onc.1204102

[28] Bridges, A.J. (2001) Chemical Inhibitors of Protein Kinases. Chemical Reviews, 101, 2541-2572. 
http://dx.doi.org/10.1021/cr000250y

[29] Xia, Y., Yang, S.Y., Hou, M.J., Kuo, S.C., Xia, P., Bastow, K.F., Nakanishi, Y., Nampoothiri, P., Hackl, T., Hamel, E. and Lee, K.H. (2001) Antitumor Agents. Part 204: Synthesis and Biological Evaluation of Substituted 2-Aryl Quinazolinones. Bioorganic \& Medicinal Chemistry Letters, 11, 1193-1196. http://dx.doi.org/10.1016/S0960-894X(01)00190-1

[30] Al-Rashood, S.T., Aboldaha, I.A., Nagi, M.N., Abou-Zeid, L.A., Abdel-Aziz, A.A., Abdel-Hamide, S.G., Youssef, K.M., Al-Obaid, A.M. and Subbagh, H.I. (2006) Synthesis, Dihydrofolate Reductase Inhibition, Antitumor Testing and Molecular Modeling Study of Some New 4(3H)-Quinazolinone Analogs. Bioorganic \& Medicinal Chemistry, 14, 8608-8621. http://dx.doi.org/10.1016/j.bmc.2006.08.030

[31] Converso, A., Hartingh, T., Garbaccio, R.M., Tasber, E., Richert, K., Fraley, M.E., Youwei, Y., Kreatsoulas, C., Stirdivant, S., Drakas, B., Walsh, E.S., Kelly, H., Carolyn, B.A., Xianzhi, M., Marc, A.T., Stephen, B.C., Weikang, T., Rob, L., Loura, S.L., Joan, Z.M., Vinod, S., Sanjeev, M.K., Sylvie, J.S., Poul, Z.D. and Hartman, G.D. (2009) Development of Thioquinazolinones, Allosteric Chk1 Kinase Inhibitors. Bioorganic \& Medicinal Chemistry Letters, 19, 1240-1244. http://dx.doi.org/10.1016/j.bmcl.2008.12.076

[32] Raffa, D., Edler, M.C., Daidone, G., Maggio, B., Merickech, M., Plescia, S., Schillaci, D., Bai, R. and Hamel, E. (2004) Synthesis, Cytotoxicity and Inhibitory Effect on Tubulin Polymerization of 3-Heterocyclosubstituted 2-Styrylquinazolinone. European Journal of Medicinal Chemistry, 39, 299-304. http://dx.doi.org/10.1016/j.ejmech.2003.12.009

[33] Alagarsamy, V., Revathi, S., Kalaiselvi, R., Phuvaneswari, S., Revathi, R., Amuthalakshmi, S., Vijay, S.K., Kumar, S.M.S., Angayarkanni, T., Sarathadevi, M., Saravan, K.S., Thaugatiruppathy, A., Venkatnarayanan, R. and Vankatesatermal, R. (2003) Analgesic, Anti-Inflammatory and Antibacterial Activity of Some Novel 2-Phenyl-3-(substituted methylamino)quinazolin-4(3H)-ones. Indian Journal of Pharmaceutical Sciences, 534-536.

[34] Gupta, A., Mishra, P., Kashaw, S.K., Jatav, V. and Stables, J.P. (2008) Synthesis and Anticonvulsant Activity of Some Novel 3-Arylamino/Amino-4-aryl-5-imino-Delta(2)-1,2,4-Thiadiazoline. European Journal of Medicinal Chemistry, 43, 749-754. http://dx.doi.org/10.1016/j.ejmech.2007.05.008

[35] Ashcroft, A.J., Davies, E.E. and Morgan, G.J. (2003) Aetiology of Bone Disease and the Role of Bisphosphonates in Multiple Myeloma. Lancet Oncology, 4, 284-292. http://dx.doi.org/10.1016/S1470-2045(03)01076-3

[36] Neiementowski, V. (1895) Neiementowski Quinazoline Synthesis. Journal für Praktische Chemie, 51, 564.

[37] Selvam, P., Breitenbach, J.M., Borysko, K.Z. and Drach, J.C. (2010) Synthesis, Antiviral Activity and Cytotoxicity of Some Novel 2-phenyl-3-Disubstituted Quinazolin-4(3H)-Ones. International Journal of Drug Design and Discovery, 1, 149-154.

[38] Hemalatha, K. and Girija, K. (2011) Synthesis of Some Novel 2,3-Disubstituted Quinazolinones Derivatives as Analgesic and Anti-Inflammatory Agents. International Journal of Pharmacy and Pharmaceutical Sciences, 3, 103-106.

[39] Raffa, D., Daidone, G., Maggio, B., Cascioferro, S., Plescia, F. and Schillaci, D. (2004) Synthesis, Antileukemic Activity of New 3-(5-Methylisoxazol-3-yl) and 3-(Pyrimidin-2-yl)-2-styrylquinazolin-4(3H)-ones. IL Farmaco, 59, 451455. http://dx.doi.org/10.1016/j.farmac.2003.10.006

[40] Jatav, V., Kashwa, S. and Mishra, P. (2008) Synthesis, Antibacterial and Antifungal Activity of Some Novel 3-[5-(4Substituted phenyl)1,3,4-thiadiazol-2-yl]-2-styrylquinazolin-4(3H)-ones. Medicinal Chemistry Research, 17, $169-181$. http://dx.doi.org/10.1007/s00044-007-9047-2

[41] Okano, M., Mito, J., Maruyama, Y., Masuda, H., Niwa, T., Nakagawa, S., Nakamura, Y. and Matsceura, A. (2009) Discovery and Structure-Activity Relationships of 4-Aminoquinazoline, a Novel Class of Opioid Receptor Like-1(ORL1) Antagonists. Bioorganic \& Medicinal Chemistry, 17, 119-132. http://dx.doi.org/10.1016/j.bmc.2008.11.012

[42] Amin, K.M., Georgey, H.H. and Awadallah, F.M. (2011) EGFR Tyrosine Kinase Targeted Compounds: Synthesis, Docking Study and in Vitro Antitumor Activity of Some Newquinazoline and Benzo[d]isothiazole Derivatives. Medicinal Chemistry Research, 20, 1042-1053. http://dx.doi.org/10.1007/s00044-010-9437-8

[43] Stadlbauer, W., Fiala, W., Fisher, M. and Hojas, J. (2000) Thermal Cyclization of 4-Azido-3-nitropyridine-2-suroxanes. Journal of Heterocyclic Chemistry, 37, 1253-1256. http://dx.doi.org/10.1002/jhet.5570370537

[44] Chandrappa, S., Prasad, S.B.B., Vinaya, K., Kumar, C.S.A., Thimmegowda, N.R. and Rangappa, K.S. (2008) Synthesis and in Vitro Antiproliferative Activity against Human Cancer Cell Lines of Novel 5-(4-Methyl-benzylidine)-thiazolidino-2,4diones. Investigational New Drugs, 26, 437-444. http://dx.doi.org/10.1007/s10637-008-9130-7

[45] Yurchenko, R.I., Ponomarenko, A.D., Savina, N.S. and Tolmachev, A.A. (2004) 2-(1-Adamantyl)-7-methylimidazo[1,2-a]pyridine and Its Reactions with N-Bromosuccinimide. Chemistry of Heterocyclic Compounds, 40, 1543-1545.

[46] Berest, G.G., Voskoboynik, O.Y., Kovalenko, S.I., Antypenko, O.M., Nosulenko, I.S., Katsev, A.M. and Shandrovskaya, O.S. (2011) Synthesis and Biological Activity of Novel N-Cycloalkyl-(cycloalkylaryl)-2-[(3-R-2-oxo-2H[1,2,4]triazino[2,3-c]quinazolin-6-yl)thio]acetamides. European Journal of Medicinal Chemistry, 46, 6066-6074. http://dx.doi.org/10.1016/j.ejmech.2011.10.022

[47] Abouzid, K. and Shouman, S. (2008) Design, Synthesis and in Vitro Antitumor Activity of 4-Aminoquinoline and 4- 
Aminoquinazoline Derivatives Targeting EGFR Tyrosine Kinase. Bioorganic \& Medicinal Chemistry, 16, 7543-7551. http://dx.doi.org/10.1016/j.bmc.2008.07.038

[48] Chemical Computing Group (2005) Molecular Operating Enviroment (MOE). Version 2005.06, Chemical Computing Group, Inc. Montreal. http://www.chemcomp.com

[49] Mosmann, T. (1983) Rapid Colorimetric Assay for Cellular Growth and Survival Application to Proliferation and Cytotoxicity Assays. Journal of Immunological Methods, 65, 55-63. http://dx.doi.org/10.1016/0022-1759(83)90303-4

[50] Vijayan, P., Raghu, C., Ashok, G., Dhanaraj, S.A. and Suresh, B. (2004) Antiviral Activity of Medicinal Plants of Nilgiris. Indian Journal of Medical Research, 120, 24-29. 